\title{
The Swamps of Home: Marsh Formation and Settlement in the Early Medieval Near East*
}

\author{
A. AsA EgER, University of North Carolina, Greensboro
}

“. . The swamps of home are brushed with green and gold at break of day. In my soul is the beauty of the bog, in my memory the magic of the mud. I know that blood is thicker than water but the swamps of home are thicker than blood."

— "Swamps of Home," Once Upon a Mattress

In studies of settlement and landscape archaeology in the Near East, marshes have only recently featured in discussions, having often been relegated to the liminalized frontiers of settlement: the uninhabitable wildernesses occupying the edges of both town and countryside. This is in contrast to the larger role played by marshes and bogs in Europe and Central and South America for settlement and land use. However, evidence from archaeological survey, coring and excavation, primary sources, and ethnographic studies has suggested that marsh wetlands in the Near East featured prominently in the human landscape. They were areas that were rich in renewable natural resources and provided transportation corridors and zones of settlement. In pursuing the evidence for wetland formation, a noticeable pattern arises during the Early Medieval period (the end of the Late Roman

* I would like to thank Timothy Beach, Canan Cakırlar, Carrie Hritz, Jesse Casana, and Tony Wilkinson for their invaluable help with this paper throughout its various iterations. Any mistakes appearing in the text are my own responsibility. period through the beginning of the Early Islamic period, sixth to eighth centuries) when marshes form and develop consistently, encompassing significant parts of otherwise prime lowland areas for cultivation. ${ }^{1}$ While low-lying regions, where marshes appear, have in all cases been susceptible to becoming periodic and seasonal wetlands, the Late Roman/Early Islamic marshes characteristically (a) became permanent all year round rather than seasonal, and often contained a body of standing water or lake; (b) continued to expand; and (c) all formed concurrently (roughly between the fifth and eighth centuries) throughout the Near East. In examples from both the Near East and

\footnotetext{
${ }^{1}$ In this paper, the term "Late Roman" is used to denote the fourth to mid-seventh centuries rather than the terms "Byzantine" or "Late Antique," as Late Roman carries within it the idea of Roman continuity, seen in the landscape and settlement patterns. The term "Early Medieval", though problematic in referring to nonWestern Islamic culture, is suitably general to include both the Late Roman and Early Islamic periods (particularly in frontier regions) mainly referred to in the paper, the sixth-eighth centuries C.E.
} 
Pre-Columbian civilizations, ${ }^{2}$ the causes for this have been debated as either natural (due to climatic shifts and seasonal inundations) or anthropogenic (due to increased land exploitation and intensive cultivation). With respect to the latter, a strong link is established between the potential human-induced factors for marsh formation and its use as a mode of subsistence.

This article will address the problems of formation and settlement in two parts. The first part will examine scientific and literary evidence regarding the formation of three marshland areas in the Near East and consider how that formation was related to anthropogenic factors. What becomes clear is that, beginning in the Hellenistic period and peaking by the Early Islamic period, a combination of human factors, including deforestation and the expansion of stateorganized irrigation systems, led to the transformation of several seasonal lakes and marshes into permanent wetlands. The second part will show how this led to the development of adaptations by which people settled in wetlands and subsisted from the marsh ecology, particularly in the Early Islamic period and later, following the Late Roman period when population and settlements generally reached a peak throughout the countryside. ${ }^{3}$

This process had an important impact on the main point of contact between the Early Islamic caliphate and the Byzantine Empire: the thughīr and 'awassim frontier areas such as the Amuq and Maraş corridor. By understanding the ways in which social and eco-

\footnotetext{
${ }^{2}$ The general pattern of marsh formation (as well as debates over its natural or anthropogenic causes) is symptomatically and syncretically not confined to the Near East, but is closely paralleled in Central and South America and other parts of the Mediterranean, i.e., the Distré Swamp in France; see Anne Laure Cyprien, Nathalie Carcaud, and Lionel Visset, "Étude paleoenvironnementale du Marais de Distré (Saumorois): Géoarchéologie d'une zone humide depuis le préboréal" Quaternaire 12.1-2 (2001): 89-101. For natural causes in the Mayan wetlands of Central and South America, see Sheryl Luzzadder-Beach and Timothy Beach, "Wetlands as the Intersection of Soils, Water, and Indigenous Human Society in the Americas," in Soils and Societies: Perspectives from Environmental History, ed. John R. McNeill and Verena Winiwarter (Isle of Harris, The Hebrides, 2006), 91-117, which includes the scholarship and position Isle of Harris, The Hebrides on the duality of anthropogenic and natural factors.

${ }^{3}$ For a good summary of the archaeological work related to the Late Roman peak in settlement in the Near East, see Chris Wickham, Framing the Early Middle Ages: Europe and the Mediterranean 400-800 (New York, 2005), 443-54.
}

nomic systems developed in relation to the formation of permanent marshlands in the Near East in Late Antiquity, we can establish a framework for examining choices made in Late Roman and Islamic settlement patterns.

\section{Formation}

The existence and formation of freshwater marshes has often been understood and accepted as part of a natural process of climatic and geological change. A freshwater marsh is a class of wetland ecosystem that is widespread and characterized by seasonal to permanent flooding. ${ }^{4}$ When these marshes expand to over eight hectares $\left(.08 \mathrm{~km}^{2}\right)$, they can be considered lakes. ${ }^{5}$ As a wetland, it is generally defined by three features (1) soils formed from saturated conditions that develop partially anaerobic properties (hydric soils), (2) aquatic plants adapted to live in these soils (hydrophytes), and (3) high water tables where water is near the surface or just above the water table for part of the season. Several physical factors create wetlands and are caused by natural and anthropogenic processes: rise in sea level; change in climate and increased precipitation; erosion, causing sedimentation and flooding on the plain and in river channels; the formation of natural levees that block floodwaters from reentering the river channel; and the deliberate or natural diversion of river channels (i.e., canalization and irrigation). As such, the formation and expansion of marshes (marshification $)^{6}$ must be viewed both as

${ }^{4}$ This broad definition of wetlands (including marshes, swamps, etc.) comes from several main definitions by legislative and regulatory bodies, e.g., National Research Council, Wetlands: Characteristics and Boundaries, Commission on Geosciences, Environments, and Resources (Washington, D.C., 1995), 21, 53-59; see also the Ramsar Treaty (http://www.ramsar.org/), accessed April 24, 2009. The Ramsar Convention on Wetlands, developed in Ramsar, Iran in 1971, is an international treaty designed to establish a common framework with which to conserve and wisely use wetlands.

5 "Ramsar Classification System for Wetland Type," Ramsar Treaty (http://www.ramsar.org/).

"I use the term "marshification" (the process of becoming marshland) with the similar meaning as "desertification." Desertification refers to a process, often on desert fringes, whereby formerly productive land degrades and is no longer productive. However, marshification does not carry with it a value of degradation. Terms for marshification exist in Italian (impaludazione) and French (paludification). The English cognate, paludification, as a scientific term refers more specifically to the accumulation or extension of 


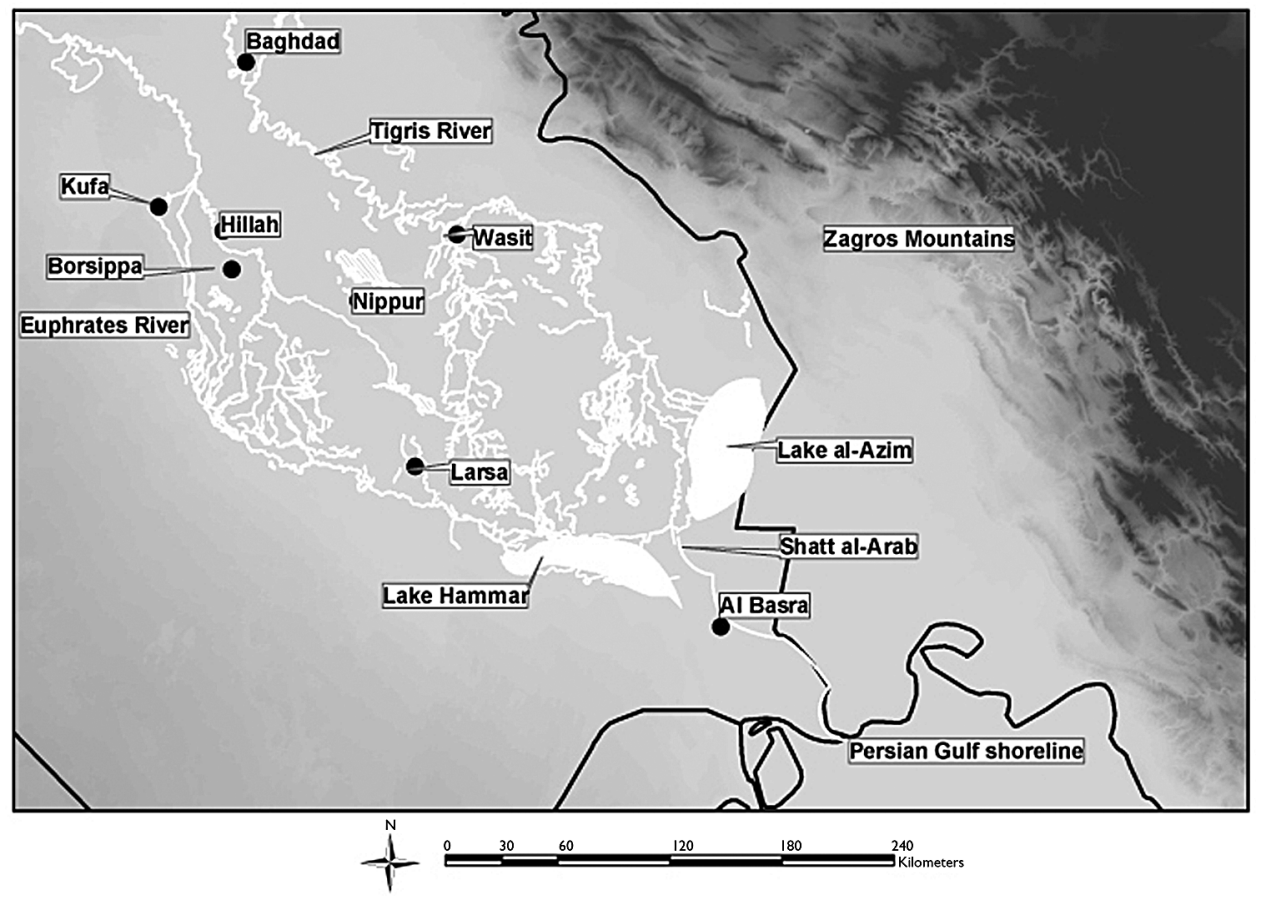

Figure 1-Southern Iraq (courtesy of Carrie Hritz).

a naturally occurring phenomenon and as an unintended consequence of increased human activity in agriculture and irrigation.

I will demonstrate through a synthesis of geomorphological, archaeological, and literary evidence that marsh formation was, more specifically, a relatively late process that occurred in separate areas in the Near East beginning around the first millennium B.C.E. Three case studies-southern Iraq (Mesopotamia), the Ghab Valley in Syria, and the Amuq Plain in Turkey - will be closely examined where marshlands are attested both through available geomorphological evidence and historical sources. ${ }^{7}$ For each case study, the physical

peat and bog that inundate higher levels. I use the term "marshification" to denote a transformation or reversion to marsh, rather than paludification, to refer to this process more generally.

${ }^{7}$ Another case study not included here is the Kahramanmaraş Valley; see Ben R. Gearey et al., "From Site to Landscape: Assessing the Potential of Geoarchaeological Data for Understanding the Archaeological Record of Domuztepe, S. E. Turkey," American Journal of Archaeology (forthcoming). For a brackish/coastal marsh case study in the Plain of Issos near Antakya, see Timothy Beach and Sheryl Luzzadder-Beach, "Aggradation around Kinet Höyük, an Archaeological Mound in the Eastern Mediterranean, Turkey" Geomorphology 17.1 (2008): 416-28. factors for wetland creation (geology and seismic history, climate and precipitation, hydrology, soils and sedimentation, and elevation range) will be presented, followed by the textual and archaeological evidence. Evidence will show that although natural factors such as climatic change and seasonal flooding were key in creating marshland zones, intensive human activity between the Seleucid/Hellenistic (beginning in the third century B.C.E.) and the Early Islamic periods (ending in the tenth century C.E.) caused these zones to develop primarily as stable (and expanding) permanent marshes and lakes by the end of the Late Roman period and the beginning of the Early Islamic period.

\section{Southern Iraq}

Perhaps the most renowned of the Near Eastern wetlands are the vast marshes of southern Iraq ( $a l-a b w \bar{a} r)$ in the lower Mesopotamian plain (see fig. 1), a depression formed tectonically as a result of the Arabian plate being subducted under the Iranian or Eurasian plate. ${ }^{8}$ Geomorphologic research in the region

${ }^{8}$ Cecile Baeteman, Laetitia Dupin, and Vanessa Heyvaert, "Geo-Environmental Investigation," in The Persian Gulf Shorelines 
has recognized the formation and extension of the marshes as a developed feature that increased over time. ${ }^{9}$ The initial process involved natural and physical changes in the climate and sea level, before and during the Holocene period, which set the scene for wetland formation in several stages. Sea-level change will create or destroy wetlands; a rise in sea level raises ground- and surface-water levels far inland. Initially, during the Last Glacial Maximum (16,000 в.C.E.), there was no marsh because groundwater was too low and the Persian Gulf was quite shallow. Then, the sea level rose during the Postglacial (12,000 B.C.E.), bringing the coastline more inland. ${ }^{10}$ Cores have revealed an initial zone of fluvial basin (pre-5000 B.C.E.) followed by a marine transgression of the Gulf during the wetter glacial period (5000-4000 B.C.E.). ${ }^{11}$ This Holocene sea-level rise of $125 \mathrm{~m}$ would have brought more sediment into the fluvial basins than the normal rivers could effectively discharge and would have contributed to the outward growth of river deltas (deltaic progradation) over time. ${ }^{12}$ In the third stage, the aridity of the climate and drop in sea level, beginning in the third millennium B.C.E. and continuing into the

and the Karkheh, Karun, and Jarrahi Rivers: A Geo-Archeological Approach. A Joint Belgo-Iranian Project. First Progress Report, ed. Herman Gasche, Akkadica 125 (2004): 155.

${ }^{9}$ Cecile Baeteman, Laetitia Dupin, and Vanessa Heyvaert, "Geo-Environmental Investigation," in The Persian Gulf Shorelines and the Karkheh, Karun, and Jarrahi Rivers: A Geo-Archaeological Approach. A Joint Belgo-Iranian Project. First Progress Report-Part 2, ed. Herman Gasche, Akkadica 126 (2005): 7. See other work by V. Hayvaert on human and environmental effects on the landscape of southern Iraq in the Middle and Late Holocene. For similar processes elsewhere, see, for example, Helmut Brückner, "Man's Impact on the Evolution of the Physical Environment in the Mediterranean Region in Historical Times," GeoJournal 13.1 (1986): 7-17; idem, "Coastal Changes in Western Turkey: Rapid Delta Progradation in Historical Times," Bulletin de l'Institut Océanographique 18 (1997): 63-74; and Ilhan Kayan, "Holocene Stratigraphy and Geomorphological Evolution of the Aegean Coastal Plains of Anatolia," Quaternary Science Reviews 18 (1999): 541-48.

${ }^{10}$ Paul Sanlaville, "The Deltaic Complex of the Lower Mesopotamian Plain and Its Evolution through Millennia," in The Iraqi Marshlands: a Human and Environmental Study, ed. Emma Nicholson and Peter Clark (London, 2002), 141; Baeteman, Dupin, and Heyvaert, "Geo-Environmental Investigation," 155.

${ }^{11}$ Adnan A. M. Aqrawi, "Stratigraphic Signatures of Climatic Change during the Holocene Evolution of the Tigris-Euphrates Delta, Lower Mesopotamia," Global and Planetary Change 28.1-4 (2001): 274-75, 282.

${ }^{12}$ Baeteman, Dupin, and Heyvaert, "Geo-Environmental Investigation," 155. second millennium, stabilized the deltaic progradation of the coasts and caused the waters of the Persian Gulf and coastline to recede significantly to their present location, leaving a scour basin that gradually filled in with saline brackish lagoons (salt marshes) and tidal flats (sabkba) over the extended delta land. ${ }^{13}$ Eventually these developed into small, permanent freshwater marshes and lakes by the first millennium B.C.E.

The hydrology of these rivers and precipitation causing more stream flow and flooding further contributed to marsh formation. The marshes are primarily watered by the Euphrates River, in addition to tributaries of the Tigris River and other rivers flowing down from the Zagros Mountains to the east. These are anastamosing rivers, characterized by deeply incised and straighter channels that often diverge and rejoin and associated with a large floodplain between them and along their levees. ${ }^{14}$ Following the stabilization of the coasts and sea level, flooding and sedimentation of the lower courses of the river were the main cause of the creation of marshes. ${ }^{15}$ From the upper courses of the Euphrates and Tigris Rivers and the sharply inclined slopes of the Zagros there was a strong discharge of seasonal floodwaters and surface runoff of high-energy flows containing sediment. This contributed to gradual silting of the river and streambeds upstream of the lower Mesopotamian basin around Baghdad, which eventually led to avulsion whereby the river overflowed its banks and spilled onto the river plain. Gradually, these overflows formed new river beds and so the Tigris and Euphrates Rivers have shifted across the plain. This was augmented by the lack of incised river channels on the plain. Further

\footnotetext{
${ }^{13}$ Sanlaville, "Deltaic Complex," 142; Baeteman, Dupin, and Heyvaert, "Geo-Environmental Investigation," 158. However, contemporary texts may indicate that the coastline fluctuated back and forth between Naysan (Alexandria-on-the-Tigris/Spasinou Charax) north of Bașra and Abadan south of Bașra even more between the fourth century B.C.E. and the tenth century C.E. For a more detailed discussion, see Steven Cole and Herman Gasche, "Documentary and Other Archaeological Evidence Bearing on the Identification and Location of the Rivers of Lower Khuzestan and the Position of the Head of the Persian Gulf ca. 1200 BC-200 AD," in The Persian Gulf Shorelines and the Karkheh, Karun, and Jarrabi Rivers: A GeoArcheological Approach. A Joint Belgo-Iranian Project. First Progress Report-Part 3, ed. Herman Gasche, Akkadica 128 (2007): 53-54.

${ }^{14}$ Carrie Hritz, "Landscape and Settlement in Southern Mesopotamia: a Geo-archaeological Analysis" (Ph.D. diss., University of Chicago, 2005), 43.

${ }^{15}$ Sanlaville, "Deltaic Complex," 135.
} 
downstream, in the interior fluviatile delta, the river meandering formed multiple tributary channels that drained into smaller but more numerous low basins.

Soils formed from sedimentation are another important physical factor to marsh formation: existing sands drain water well, but deposited clays will pond water. Sedimentation can be caused by natural or anthropogenic factors leading to erosion from the surrounding sandstone and limestone uplands. ${ }^{16}$ Although less significant, sedimentation can also be brought by dust storm (eolian) activity or trapped sediment in seawater in the salt marshes and sabkhas from tidal activity. ${ }^{17}$ During avulsion, the coarsest sediments settled near the riverbanks and formed high levees. The result is that the spaces between the upraised river features (alluvial ridges/levees) formed wide and shallow depressions (flood basins), often 2 to $3 \mathrm{~m}$ lower than the levees. It is in these areas where silty clay was deposited, forming the waterlogged beds for marshes and lakes. ${ }^{18}$ As these processes took place further downstream, the levees formed were smaller and the river began to lose definition.

Finally, elevation range is another important physical factor in the process of marsh formation. Marshes formed in the deepest and lowest areas of the large and flat lower Mesopotamian plain, the main area for sedimentation stretching $200 \mathrm{~km}$ wide. In this final zone of marsh and lake in the lowest part of the plain, the groundwater table is higher and the last sediments forming clayey silt beds were deposited here, obstructed from continued movement by the low energy of the water and the dense vegetation. ${ }^{19}$

The fourth stage of wetland formation occurred relatively late, by the sixth-eighth centuries C.E. Carbon-dated cores show that between 600 and 700 C.E. the sedimentation from the rivers was greater than the rate of sea-level rise and thus the coasts started to prograde farther, the coastal sabkhas were replaced by floodplain, and freshwater marshes formed in the river estuaries. ${ }^{20}$ By the seventh century C.E., the process of marsh formation had stabilized into an enormous wet-

\footnotetext{
${ }^{16}$ These uplands were susceptible to erosion and constituted the main sources of sediment for the plain; see Baeteman, Dupin, and Heyvaert, "Geo-Environmental Investigation," 158.

${ }^{17}$ Ibid., 160.

${ }^{18}$ Sanlaville, "Deltaic Complex," 137.

${ }^{19}$ Ibid., 138.

${ }^{20}$ Baeteman, Dupin, and Heyvaert, "Geo-Environmental Investigation," 7.
}

land $(370 \times 90 \mathrm{~km})$. Furthermore, the outlet of the Tigris and Euphrates into the Gulf (the Shatt al-`Arab) formed in the eighth-tenth centuries. ${ }^{21}$ It is likely that this channel provided both a drain for the marshes and access from the Gulf through them to Baghdad. This is corroborated by Pournelle, who also asserted that the heart of the wetlands of the lower Euphrates and Gulf outlets (the Ahwār marshes), the permanent freshwater Lake Hammar (Hawr al-Hammar), and the secondary Lake al-Azim (Hawr al-Hawiza) were relatively recent creations, as was the Shatt al-'Arab. ${ }^{22}$ Around 600 C.E., the Tigris flooded down the Shatt al-Gharraf over the banks of the Euphrates, causing the avulsion of the Euphrates that flooded the basin and created Lake Hammar. ${ }^{23}$ The late formation of these features is supported by cores from the Lake Hammar bed covered with 5 to $10 \mathrm{~cm}$ of organic rich sand and silt and dark clayey silt sediments with freshwater mollusks from the Larsa-Oueili area that were carbon dated to 975-1445 C.E., after the collapse of the 'Abbāsid caliphate. ${ }^{24}$ Recent cores just east of the Lake al-Azim marshes (Hawr al-Hawiza) and south of the Karkheh River in Khuzistan, Iran showed the transformation of brackish tidal lagoons to fluvial-origin freshwater marshes with dense vegetation and freshwater mollusks (stage three to stage four). The thin organic mud layer (gyttja) of stage four that overlay the brackish tidal blue mud of stage three was carbon-dated to $694-764$ C.E. at the earliest. ${ }^{25}$

As we have seen, while these permanent marshlakes occurred in the Sasanian/Islamic periods, the area was always susceptible to forming wetlands. This process of marsh formation has been viewed until recently as a solely natural process, though a complex one, involving changes to hydrology and sedimentation beyond simply tectonic subsidence or marine

${ }^{21}$ Aqrawi, "Stratigraphic Signatures," 280.

${ }^{22}$ Jennifer R. Pournelle, "Marshland of Cities: Deltaic Landscapes and the Evolution of Early Mesopotamian Civilizations" (Ph.D. diss., University of California, San Diego, 2003), 126-27.

${ }^{23}$ Ibid., 126-27.

${ }^{24}$ Sanlaville, "Deltaic Complex," 143-44.

${ }^{25}$ The Early Islamic dated marshes were from cores B39, B40, and B44 in Zone 2. Other cores (B51 and B9), albeit further south near the Persian Gulf, showed this transition as having occurred even later, in the sixteenth/seventeenth centuries. It should be noted one core (B5) showed a freshwater marsh (carbon-dated 1386-1576 B.C.E.) that became a shallow pond before the phasethree formation of brackish tidal lagoons. See Baeteman, Dupin, and Heyvaert, "Geo-Environmental Investigation," 206-15. 
invasion. ${ }^{26}$ Yet sedimentation is also an anthropogenic process caused by human land use. Pournelle theorizes a combination of natural and anthropogenic processes, noting that upland runoff, nonflowing (percolated) groundwater, and irrigation drains were punctuated with high-energy, sediment-carrying stream flows caused by storms. ${ }^{27}$ Thus, Pournelle argues that although the environment and climate helped to set the stage for the formation of wetlands, human activity brought them about, specifically in the late periods, with greater intensification and permanence.

Literary sources regard marsh formation as both a natural phenomenon and a cultural one. They also affirm the relatively late date for their existence. In the region of Borsippa between the eighth and sixth centuries B.C.E., texts mention that a large and permanent marsh had formed from the Hillah branch of the Euphrates, hampering the construction of canals, and isolated the area. ${ }^{28}$ The shifting of the Euphrates supplied Borsippa with more water but left important urban centers such as Nippur dry. This in turn demanded continuous manipulations by various Assyrian and Neo-Babylonian kings, including diverting water to flood other parts of the plain and intentionally creating marshes. ${ }^{29}$ The marshes were used to water

\footnotetext{
${ }^{26}$ For tectonic subsidence and marine incursions see George Murray Lees and Norman Leslie Falcon, "The Geographical History of the Mesopotamian Plains," Geographical Journal 118 (1952): 38. Sanlaville and Aqrawi diverge on the problem of sedimentation. Sanlaville ("Deltaic Complex," 137) noted briefly that silting from irrigation might also have been a factor. Aqrawi ("Stratigraphic Signatures," 279) adds that low precipitation and reduced sediment were also important factors in marsh formation. Unfortunately, further discussion is not provided to better explain the puzzling and seemingly incongruous statement that low sedimentation resulted in increased marsh formation.

${ }^{27}$ Pournelle, "Marshland of Cities," 75, 108.

${ }^{28}$ It was known as Tamtu, or "the Sea." The texts also gave various channels by name and charted the formation of new channels. See Steven Cole, "Marsh Formation in the Borsippa Region and the Course of the Lower Euphrates," Journal of Near Eastern Studies 53 (1994): 87.

${ }^{29}$ Nebuchadnezzar II (604-562 B.C.E.), in order to prevent flooding, resorted to diverting water to flood other parts of the plain (Cole, "Marsh Formation," 94). Sennacherib's (704-681 B.C.E.) attempts to restore the original channels to redistribute the water supply resulted in flooding and the formation of marshes around Babylon (Cole, "Marsh Formation," 90, 92). Interestingly, Russell's analysis of the palace reliefs and inscriptions from Nineveh show that Sennacherib created the swamp intentionally as a drain outlet for overflow from a canal irrigation system: "To calm the
}

cultivated parts of the plain,,$^{30}$ and they also acted as defense barriers (like moats) around cities. ${ }^{31}$ Archaeological survey confirms that the real change to the landscape took place between the Neo-Babylonian and Seleucid periods (600-300 в.C.E.). By this period, the dendritic network of canals that was in place was intensified by a program of constant maintenance to prevent silting and avulsion. ${ }^{32}$ Early central administrative systems of the first millennium B.C.E. were strongly linked with the shaping of the landscape of southern Iraq and the formation of the marshes. Yet, the example from the Neo-Babylonian period shows how state-run infrastructure maintained a precarious and precious balance of canal irrigation systems and swamps as drainage and defense systems around urban communities - a balance that could be easily tipped with agricultural and irrigation intensification and several periods of severe precipitation and flooding.

In the late first century B.C.E., Strabo (63/4 B.C.E. -24 C.E.) describes the process of marsh formation through both natural and human factors including irrigation and the impact of canalization on the landscape:

... the Euphrates rises to flood-tide at the beginning of the summer . . so that of necessity it forms lakes and deluges the ploughed lands, unless the excess of the stream, or the surface water is distributed by means of trenches and canals. . . Now this is the origin of the canals; but there is need of much labour to keep them

rush of the waters for the orchards, I created a swamp and planted a canebrake in it. Herons, wild pigs, and deer I turned loose therein .... The canebrakes flourished luxuriantly, the high-flying heron built his nest there, and the wild pigs and deer multiplied abundantly" (text from the door ' $c$ ' colossus) (Thorkild Jacobsen and Seton Lloyd, Sennacherib's Aqueduct at Jerwan [Chicago, 1935], 35 , n. 20, translated in John M. Russell, Sennacherib's Palace Without Rival at Nineveh [Chicago, 1992], 259).

${ }^{30}$ Another text from the palace reliefs states: "In the summer I watered all of the orchards; in the winter, a thousand fields in the plain above and below the city I watered, yearly." See Russell, Sennacherib, 260, n. 38.

${ }^{31}$ In 587 в.C.E., Queen Nitocris, the wife of Nebuchadnezzar II, dug a marsh north of Babylon for defensive protection. It was such an expanse of marsh that it delayed Alexander the Great, in 331 B.C.E., from his conquest of Mesopotamia. For both Nitocris and Alexander, see Cole, "Marsh Formation," 95-96.

${ }^{32}$ Robert McC. Adams and Hans J. Nissen, The Uruk Countryside (Chicago, 1972), 57. 
up, for the soil is so deep and soft and yielding that it is easily swept out by the streams, and the plains are laid bare, and the canals are easily filled, and their mouths choked, by the silt; and thus it results again that the overflow of the waters, emptying into the plains near the sea, forms lakes and marshes and reed-beds. . . ${ }^{33}$

Just before the end of the Parthian period (midthird century C.E.), the marsh began to extend considerably north, inundating agricultural and occupied lands. ${ }^{34}$ Also at this time, the Euphrates was only navigable as far as the Hawr al-Hammar in the direction of the Persian Gulf; the old bed further south past Bassra was completely inundated. ${ }^{35}$ In the fifth century C.E., the only marsh identified on the Peutinger Table was the lower Mesopotamian wetland, indicating that it must have been rather prominent and vast as compared with any other part of the Mediterranean. ${ }^{36}$ During the Islamic period the area was referred to as the Great Swamp ( $\left.a l-b a t \bar{a}^{\prime} i \not h\right)$, a vast expanse of roughly $20,000 \mathrm{~km}^{2}$. The Muslim geographers commented extensively on the complex system of canals that traversed the plain from the Euphrates to the Tigris. Indeed, this system of irrigation, which had been greatly improved and enlarged by the Sasanians, reached its peak during the Early Islamic period. Many of the major canals that flowed into the swamps were individually named and appear in the texts of Islamic geographers such as Yākūt, Ibn Rustah, and Ibn Serapion. In the tenth century, Ibn Hawqal wrote that Bașra had one hundred thousand canals in its territory. ${ }^{37}$

Regarding the process of marsh formation, Balādhurī dated it to the reign of the Sasanian king Kubadh I at the end of the fifth century C.E. He astutely attributed the marsh formation process to two main and tenable reasons. First, a series of floods,

\footnotetext{
${ }^{33}$ In academic fashion, Strabo introduced other theories on the formation of the marsh, such as Polycleitus's who asserted that it was the Tigris and not the Euphrates that flooded the plain. Strabo picked this argument apart and demonstrated that it was "the sideoutflows of the Euphrates which form the lakes near Arabia and the marshes ... near the Persian Sea. . ”S Strabo, Geog., 16.1.9-12.

${ }^{34}$ This is the first of two main episodic movements of the marsh according to Adams; see Adams and Nissen, Uruk Countryside, 59.

${ }^{35}$ For more discussion on these sources, see Cole and Gasche, "Documentary and Other Archaeological Evidence," 22.

${ }^{36}$ Giusto Traina, Paludi e bonifiche del mondo antico (Rome, 1988), 91 .

${ }^{37}$ Ibn Hawqal, Kitāb ṣūrat al-ārdd (Beirut, 1964), 212.
}

broken dikes, and avulsion started the process. In the subsequent reign of Anushirwan, these dikes were repaired and the land was reclaimed from inundation. However, in 629 during the reign of Khusraw Parwiz, around the time of the hijra of Muhammad, there was a great flood caused by seismic activity and the marshes began to become permanent. ${ }^{38}$ Second, during the Early Islamic conquests of Iraq, the Persians "were kept too busy fighting to mind the breaches which would burst and no one would mind them; and the feudal lords [dibkān] failed to block them. Consequently, al-Batịhah was made wider and more extensive." "39 For Balādhurī, the avulsion of the flooded Euphrates and Tigris rivers and neglect in maintaining the rivers led to the formation of the marsh at the end of the fifth century C.E. He states further that the administrators and ruling nobles viewed the marsh as wasteland and they either spent considerable money to reclaim it or attempted to contain the marsh (and drain the land) by further canalization. Left untended, however, these canals would have eventually led to further marshification by creating a wider network of waterways that could eventually flood.

The heavy hand of human exploitation of the region's water sources must be recognized as a principal factor in the formation of the marshes, given the susceptibility of the low-lying terrain to become permanently waterlogged. The cities of the Mesopotamian delta would have been surrounded by marshland. This would have increased with peaks in settlements in the Sasanian period and in the Early Islamic period. ${ }^{40}$ The settlement explosion came with intensive canal building that similarly peaked in the Sasanian period and continued through the Early Islamic period. Maintenance of the canal systems and marshes continued through the Islamic periods, particularly under the 'Abbāsid caliph Hārūn al-Rashīd. Attendant canals

${ }^{38}$ al-Balādhurī, Futūḥ al-buldān (Beirut, 1957-1958), 410-11. According to Adams (and from the literary evidence), this is the second extension of the marsh (Adams and Nissen, The Uruk Countryside, 59). As Adams noted, it is difficult to attribute the creation of permanent swamps to one or two floods; however, he does not preclude the impact of seismic activity.

${ }^{39}$ al-Balādhurī, Futūh al-buld̄̄n, 41 l, translation following P. K. Hitti, trans., Origins of the Islamic State (Piscataway, 2002), 455.

${ }^{40}$ Pournelle, "Marshland of Cities," 203, fig. 82. The peak was in the Sasanian period (656 sites) followed by the Early Islamic period (422 sites). See n. 115 below, for detailed information on the surveys and settlement numbers. 
during the Sasanian/Early Islamic periods would have increased the potential for flooding, avulsion, and wetland formation. There is also evidence that by the Early Islamic period canals were abandoned and flooded. ${ }^{41}$ Flooded canals became deeper waterways within the marshes and transportation corridors:

We left the sheltering reeds, and entered a broad stream of clear water, the channel running straight ahead as far as the eye could see, as though cut by the hand of man; as indeed it must have been, for it was a fragment of the famous Nahrawan Canal, one of the great irrigation works which of old made Mesopotamia a fertile land.... Traces of the old irrigation system were easily discernible-straight canals with distributaries taking off at regular intervals, in marked contrast to the meandering, ill-designed channels dug by the Arab of today. These old canals are to be traced, not as might be expected by depressions, but by ridges, the remains of the ancient soil banks. ${ }^{42}$

The fragility of the canal systems within the balance of settlement and increasing permanent wetlands can be seen at the site of Bașra, an Early Islamic newly founded misr. Flood and alluvium deposits were found covering an earlier (presumably initially Islamic) settlement at Bașra over which the successive settlement was built. ${ }^{43}$ The example of Bașra helps to illustrate the vulnerability of the marshlands of southern Iraq with regard to a large canal and urban infrastructure. The canal system became a point of weakness for the 'Abbāsids and successive empires, particularly when the canals and surrounding fields were destroyed

\footnotetext{
${ }^{41}$ Between the Shatt al-Arab and the tidal areas, a large area of abandoned irrigated canals was documented dating to the "Abbāsid period; see Lees and Falcon, "The Geographical History," 34. Hritz, using remote sensing and survey data to track shifting channels and new channel systems, recorded a levee in Lake Dalmaj by its attendant sites as Parthian, although at its eastern end the levee was covered by Early Islamic sites showing the abandonment and presumed flooding of the channel ("Landscape and Settlement," 104, 197-98). The Lake Dalmaj basin became part of the Great Swamp in the Islamic period and has remained, more or less, a permanent waterlogged area until today.

${ }^{42}$ Fulanain, Haji Rikkan, Marsh Arab (London, 1927), 22-23, 42 .

${ }^{43}$ Lees and Falcon, “The Geographical History,” 36.
}

during the conquest of Baghdad by the Mongols in 1258 and the Timurids in $1401 . .^{44}$

To sum up, geomorphological, literary, and archaeological evidence points to a highly susceptible wetland depression area in the basins of the lower courses of the Tigris and Euphrates in southern Iraq. Beginning in the Neo-Babylonian period and greatly increasing into the Sasanian and Early Islamic periods, the complex system of irrigated canals, engineered through state-sponsored activities, spread over the area creating arable fields. A vicious cycle was created, however, in that the network of canals was widened in efforts to depressurize the impact of the seasonal floodwaters of the rivers and the occurrence of avulsion. This system, requiring constant maintenance and strong administrative control, was highly vulnerable to changes in the political regime. The consequences of abandonment and the collapse of the canal systems transformed fields into wetlands and flooded canals into waterways.

\section{Ghab Valley}

The Ghab Valley, inscribed by the central stretch of the Orontes River in Syria, occupies a very different ecological setting than the lowland floodplains of southern Iraq. More similar to the topography of the Amuq Plain and the Byzantine/Islamic frontier zone, its difference lies in the proximity of upland mountain zones surrounding the valleys that fall within rainfed cultivation zones (see fig. 2). Situated between limestone and dolomite mountain ranges, the Ghab (meaning 'jungle') is a large wetland depression $10 \mathrm{~km}$ $\times 60 \mathrm{~km}$ over a karstic bed along the Orontes that widens out considerably between two narrow gorges near Apamea/Afāmiya and Shayzar (to the south and east) and Tell Qarqūr and Jisr Shughūr (to the north). Near this last location, an early Pliocene-Pleistocene basalt flow acted as a dam for the river flowing north, contributing to the susceptibility of wetland formation. Although the Ghab has been a permanent marsh, it expanded seasonally owing to the increased water flow of the Orontes River in the winter. Weulersse

${ }^{44}$ For more on the socioeconomic consequences of the fragility of the canal and agrarian systems of southern Iraq during the Middle Islamic period, see Marshall Hodgson, The Venture of Islam: Conscience and History in a World Civilization, vol. 2: The Expansion of Islam in the Middle Periods (Chicago, 1974), 387-91. 


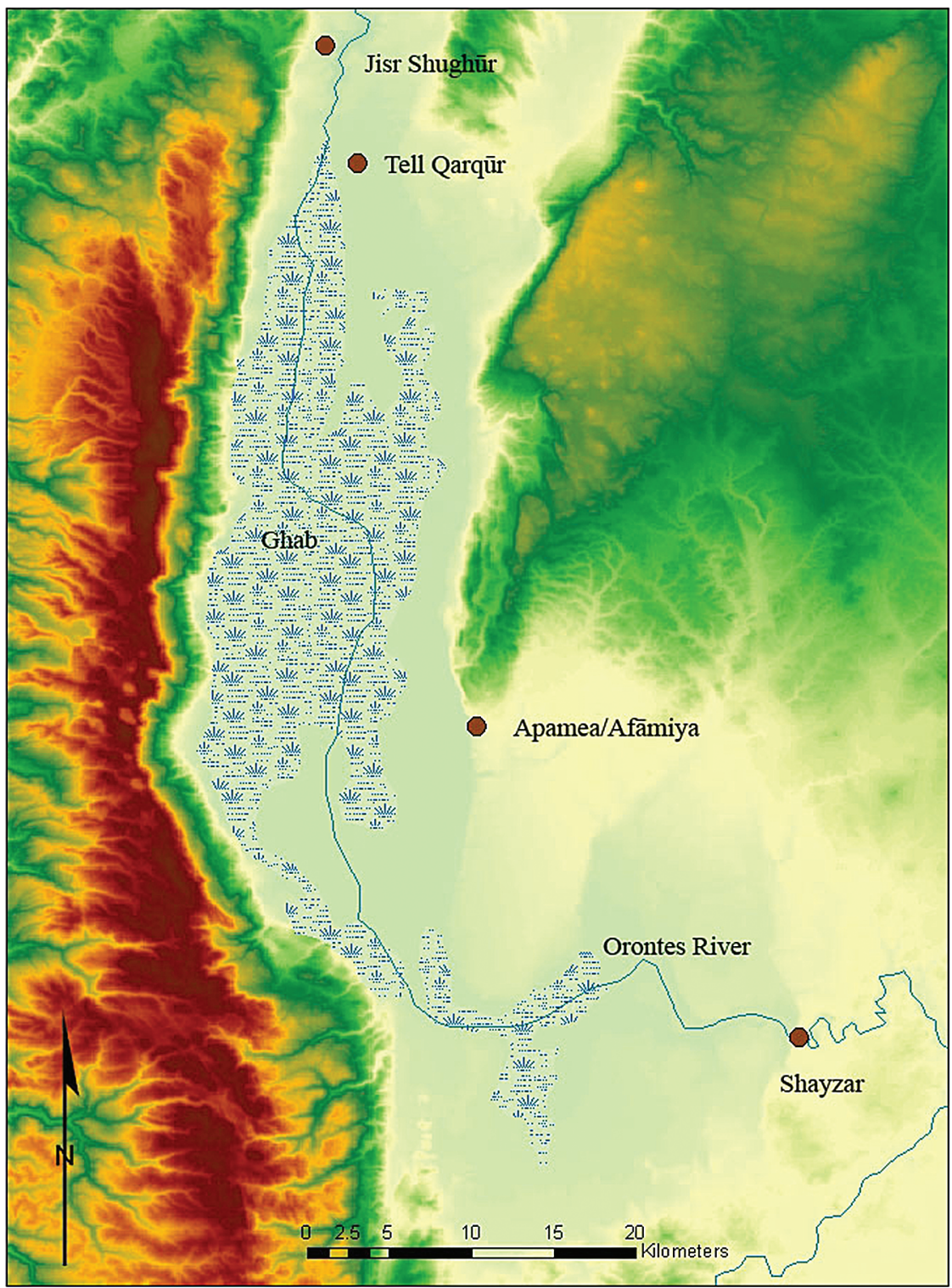

Figure 2-Ghab Valley.

recorded that between November and March the volume of water increased from $11 \mathrm{~m}^{3}$ to $100-200 \mathrm{~m}^{3}$ / sec. ${ }^{45}$ The flatness of the plain and the relative impermeability of the ground prevented the water from draining properly. The exit channel of the Ghab near Qarqūr was artificially constructed and diverted from the narrow outlet around the tell. Several separate

\footnotetext{
${ }^{45}$ Jacques Weulersse, Le Pays des Alaonites, vol. 1 (Tours,
} 1940), 71 . basins connected by waterways that have over time become inundated and marshy formed the Ghab plain. ${ }^{46}$

The Ghab was initially dominated by desert steppe during the Late Glacial. Around 9000 B.C.E. it was a forest, indicating higher temperatures and precipitation. ${ }^{47}$ Between 7000 and 5700 B.C.E. there was a decrease in oak and increase in charcoal, ferns,

${ }^{46}$ Ibid., 71, 74-75.

${ }^{47}$ Willem Van Zeist and Henk Woldring, "Holocene Vegetation and Climate of Northwestern Syria," Palaeohistoria 22 (1980): 117-20. 
and moss, as well as olive pollen. The process of deforestation and soil erosion that led to the infilling of the valley and the formation of a lacustrine environment dates to the Bronze Age. ${ }^{48}$ Between 2900 B.C.E. and 1000 C.E., the olive pollen reached its high point and an increase in wetland vegetation indicates a change from lake to marsh. ${ }^{49}$ This is coupled with a rapid decline in deciduous oak and a rise in grape and other fruit trees. ${ }^{50}$ This indicates massive deforestation and intensive cultivation of Mediterranean staple products, olive oil and wine. The time range for the spread of olive and growth of marsh is rather long according to the studies by Yasuda et al. (see n. 48) and hinders finer dating. It may be correlated with the other studies in the Levant, such as cores in the Huleh Valley and Lake Kinneret in Israel, that pointed to decline in pine and oak and an increase in olive pollen around 250 в.С.E. ${ }^{51}$ Intensification of olive cultivation between the Seleucid and Late Roman/Early Islamic periods would have induced upland soil erosion on the plain and stimulated marsh growth. However, CORONA imagery shows that the marsh was drained and the river made navigable; several prominent linear canal features bisected the marshland basin dating (based on sites along the canals) from the Roman/Late Roman to Middle Islamic periods. ${ }^{52}$

${ }^{48}$ John Meadows, "The Younger Dryas Episode and the Radiocarbon Chronologies of the Lake Huleh and Ghab Valley Pollen Diagrams, Israel and Syria," The Holocene 15.4 (2005): 631-36. However, arguments have been made for an earlier Neolithic date for deforestation; see Yoshinori Yasuda, Hiroyuki Kitagawa, and Takeshi Nakagawa, "The Earliest Record of Major Anthropogenic Deforestation in the Ghab Valley, Northwest Syria: A Palynological Study," Quaternary International 73/74 (2000): 127-36.

${ }^{49}$ Ibid.

${ }^{50}$ Van Zeist and Woldring, "Holocene Vegetation," 117-20.

${ }^{51}$ Uri Baruch and Sytze Bottema, "A New Pollen Diagram from Lake Hula: Vegetational, Climatic, and Anthropogenic Implications," in Ancient Lakes: Their Cultural and Biological Diversity, ed. Hiroya Kawanabe, George W. Coulter, and Anna C. Roosevelt (Ghent, 1999), 75-86. One potential problem with the study of Yasuda, Kitagawa, and Nakagawa ("Earliest Record," 129) was with the dating method, which depended on the carbon date of shells. The limestone-rich bedrock and slopes, dating much earlier, would distort the true date of the calcareous shells. This is known as the "Hard Water Effect," recognized as a factor in the study, but perhaps underestimated; see Jesse Casana, "From Alalakh to Antioch: Settlement, Land Use, and Environmental Change in the Amuq Plain of Southern Turkey" (Ph.D. diss., University of Chicago, 2003), 56 .

${ }^{52}$ Casana, "From Alalakh to Antioch," 298-99; idem, "The Archaeological Landscape of Late Roman Antioch," in Culture
Presumably, the engineering attempts to drain the marshes were undertaken later than Strabo, who, writing in the early first century C.E., observed a large lake that spread into broad marshes (leimonas) near the Orontes and the large Seleucid/Hellenistic city of Apamea. ${ }^{53}$ Evidence of a spike in catfish remains (88 percent fish bone) in domestic assemblages from the city of Apamea postdates 613 C.E. when the city was razed by the Persian invasion. ${ }^{54}$ This suggests that by the Early Islamic period, the Ghab basin returned to marsh and that the canals, like those in southern Iraq at around the same period, silted up and became marsh waterways. ${ }^{55}$ By the Middle Islamic period, the plain was comprised of two permanent lakes: the lake of Afāmiya to the south and the lake of the Christians to the north. Abū al-Fidā', writing in 1321 C.E., described the southern lake as a:

number of lagoons divided one from another by beds of rushes with lowlands covered by reeds. The largest of these lagoons forms two lakes-one to the south, the other to the north. The waters thereof are derived from the river Orontes, which flows into the swamp on the south side, forming the lagoons. The river afterwards flows out again from the northern border of the swamps and lowlands. It is the southern of these two lakes which is more properly called the lake of Afamiyyah. Its width is of about half a league, its depth is less than the height of man, but its bottom is so miry, that a man cannot stand up in it. ${ }^{56}$

Regarding the northern lake, he affirmed the great waterway detected in the satellite imagery and elaborated on its importance as a transportation route: "The second great lagoon, which is to the north of

and Society in Late Roman Antioch, Proceedings of the Conference at University College, London, 15 December 2001, ed. Janet A. R. Huskinson and Isabella Sandwell (Oxford, 2002), 107-108.

${ }^{53}$ Strabo, Geog., 16.2.10.

${ }^{54}$ Wim Van Neer, "Les restes de poissons de quelques maisons d'Apamée," in Fonilles d'Apamée de Syrie, ed. Jean Ch. Balty (Brussels, 1984), 291-303.

${ }^{55}$ Casana, "From Alalakh to Antioch," 299.

${ }^{56} \mathrm{Abū}$ al-Fidā', Kitāb taqwīm al-buldān, Arabic text in M. Reinaud and M. le Baron MacGuckin de Slane, Géographie d'Aboulféda. Texte Arabe publié d'après les manuscrits de Paris et de Leyde aux frais de la Société Asiatique (Paris, 1840), 41. Translation following Guy Le Strange, Palestine under the Moslems: A Description of Syria and the Holy Land from A.D. 650-1500 (Beirut, 1965), 70. 
the first, is separated from it by the marsh land covered with reeds, through which runs a waterway, whereby boats go from the southern to the northern lagoon." ${ }^{57}$ In the process of becoming a stable, expanding, permanent marsh with lakes, parts of the Ghab basin would still have fluctuated back and forth seasonally. By the twentieth century, the Ghab wetlands were a lake that extended $80 \mathrm{~km}$ down to Shayzar and persisted through the summer months. ${ }^{58}$

To recapitulate, while between the Seleucid/Hellenistic and Late Roman period the area of southern Iraq was characterized by intensive canalization in the Ghab Valley (a basin seasonally susceptible to wetlands), upland settlement, deforestation, and intensive cultivation of olives and other products contributed to a large amount of erosion on the valley floor. The aggradation of sediment filled canals and created a permanent marshland by the Early Islamic period.

\section{Amuq Plain}

Like the Ghab, the Amuq is a low-lying depression, lying $80-100$ m.a.s.l. (meters above sea level) in elevation and measuring about $35 \times 40 \times 45 \mathrm{~km}$ (about $670 \mathrm{~km}^{2}$ ) in extent that featured a prominent lake and surrounding marsh until the middle of the twentieth century (see fig. 3). ${ }^{59}$ Like the lowlands of southern Iraq and the Ghab, marshes and standing bodies of water have existed throughout the cultural history of the Amuq plain in various intermittent, seasonal, or semipermanent forms. These were due to a combination of physical factors of geology and seismic history, climate and precipitation, and hydrology.

The Amuq Plain, continuing north to Kahramanmaraş, is part of the Rift Valley traversing the Red Sea-Dead Sea-Jordan River-Ghab Plain and is located at an intersection of major fault lines, making it a seismically active region; both depressions formed from tectonic plate subsidence twenty-five million years ago. ${ }^{60}$ The valley is virtually enclosed, flanked on three sides by highlands. To the west are the steep Amanus

\footnotetext{
${ }^{57}$ Le Strange, Palestine under the Moslems, 71.

${ }^{58}$ Joseph Fitchett and McAdams Deford, "A River Called Rebel," Saudi Aramco World 24.3 (May/June 1973).

59 'Amq meaning 'depression' in Arabic and ancient Semitic languages.

${ }^{60}$ Hüseyin Korkmaz, "Antakya-Kahramanmaraş Grabenindeki Sulak Alanların (Amik Gölü, Emen Gölü ve Gāvur Gölü Bataklığı) Dünü, Bugünü ve Geleceğ1," in Ekolojik Okur Yazarllk: Sürdürü-
}

Mountains rising 2,250 m.a.s.l., ${ }^{61}$ to the south and east are the lower limestone hills of the Jebel al-Aqra and Jebel Zawiye, which have been referred to as the massif calcaire or Syrian Jebels (400-800 m.a.s.l. but reaching a maximum of 1,200 m.a.s.l.), and to the northeast is the Kurt Dağ, a low basaltic mountain range lying at 825 m.a.s.l.

Natural causes for the formation of the lake and marsh in the Amuq Plain have traditionally been attributed to seismic activity ${ }^{62}$ and/or to heavy precipitation inundating the rivers that feed into the lake and marsh. The former is mentioned in the literary sources in at least two cases. Al-Tabarī describes a period of increased seismic activity in the region around 860 C.E. ${ }^{63}$ While marsh formation is not explicitly stated, the process can be compared with a similar account from around 1000 C.E. While staying at Anțākiya, Ibn Butlān recounts the story of an earthquake that produced a swamp. ${ }^{64}$ Woolley argued that the formation of the marsh was caused by a single earthquake. ${ }^{65}$ While

lebilir Bir Dünya İçin Amanoslar'da Doğa Eğitim, ed Yaşar Ergün, Şükran Yalçın-Özdilek, and Hatice Pamir (Hatay, 2008), 36.

${ }^{61}$ The Amanus contain traces of metal resources such as gold, copper, zinc, and lead, as well as steatite (soapstone), which were mined in the Roman-Early Islamic periods. The Amanus were also a source for lumber throughout antiquity. These two activities would have contributed to deforestation and soil erosion.

${ }^{62}$ Thomas A. Sinclair, Eastern Turkey: An Architectural and Archaeological Survey, vol. 4 (London, 1990), 293.

${ }^{63} \mathrm{Al}$-Tabarī, 34: 157; translation following S. al-Zaid, "The Apocalyptic Frontier: Tarsus and the End of the World," (paper presented at MEHAT, University of Chicago, 2004), 13. Al-Ṭabarī continues to say that the same earthquake affected much of Shām and the Syrian thughūr, including Bālis, al-Raqqa, Harrān, Ra's al'Ayn, Himș, Dimashq, Ruhā (Edessa), Ṭarsūs, Mașșīṣa, Adhana, and the coasts.

${ }^{64}$ Ibn Butlān quoted in Yāqūt, Mư jam al-Buldān (Beirut, 195557), 1:266-70, translation following Le Strange, Palestine Under the Moslems, 374-75. The following news comes from the north Anatolian town of Gangra (modern Çankırı in Paphlagonia, Anatolia): "From the crevice in the earth extremely hot water had been thrown up, flowing north from many springs. It had submerged seventy farmsteads. The people fleeing therefrom had escaped for safety to the hill-tops and high places around. The water covered the surface of the ground during seven days, spreading round about the city for the distance of two days' journey. After that time it disappeared, and the place where it had been became a swamp." This description can be compared to that of Malalas concerning the great sixth century C.E. earthquake of Antioch where he mentions "liquid mud" and "sea sand" rising from the ground that was most likely an occurrence of liquefaction (Malalas, Chron., 13.420).

${ }^{65}$ Sir Leonard Woolley, A Forgotten Kingdom (Baltimore, 1953), 19 


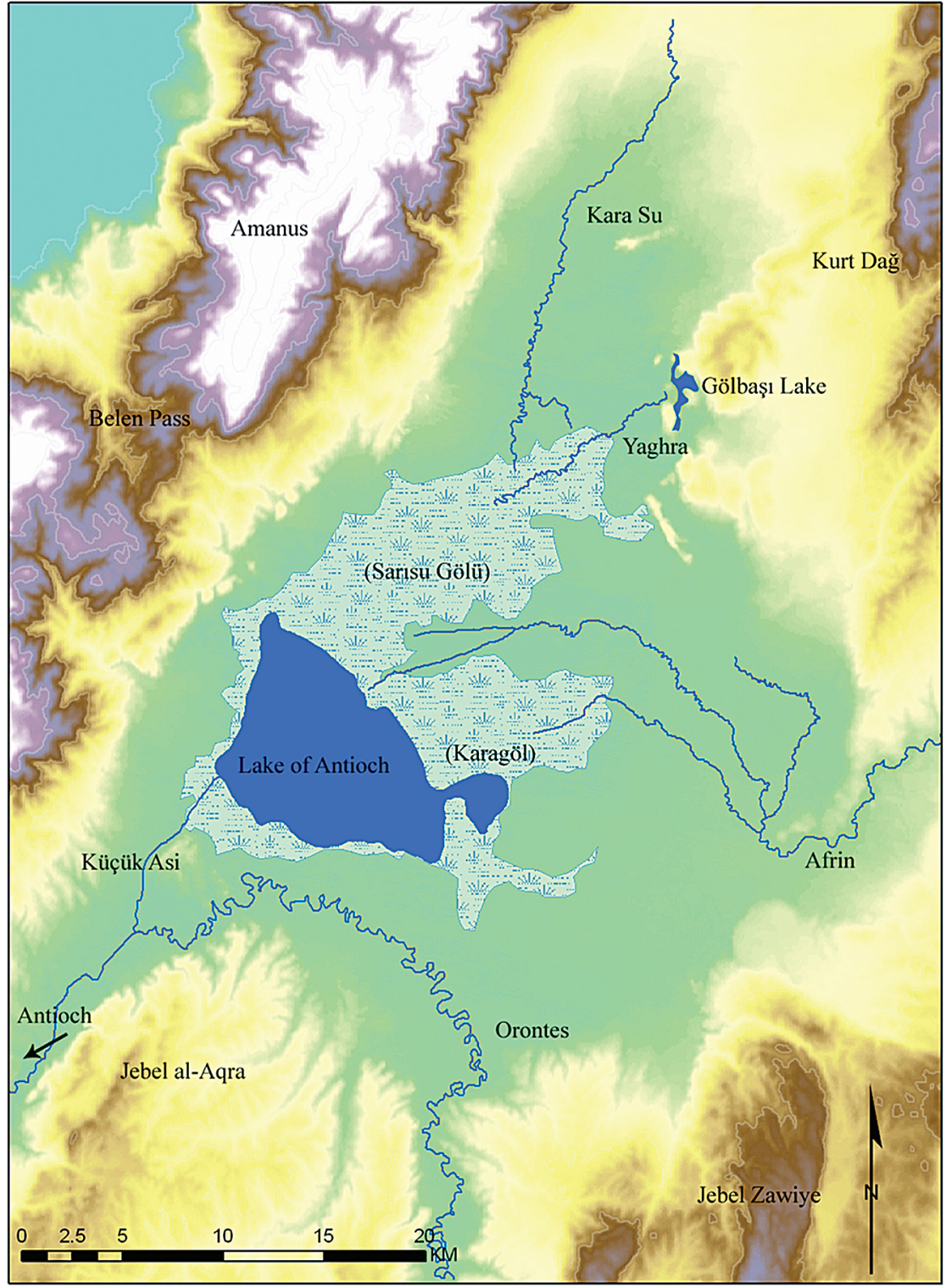

Figure 3-Amuq Plain.

the region is prone to earthquakes, the suggestion that a single or several earthquakes caused the formation of the permanent lake and marsh alone is not supported by geological evidence.

Precipitation, however, may have been more influential. Local rainfall in the twentieth century shows that the area around Antakya receives more rainfall $(50-1500 \mathrm{~mm} /$ year $)$ in relation to other areas in the region, beginning in late September/early October, peaking in December and January, and continuing until April. ${ }^{66}$ However, Antakya may not be representative of the entirety of the Amuq. Annual rainfall in the 1930s was recorded as $900 \mathrm{~mm} /$ year for Antakya but only $500 \mathrm{~mm} /$ year for Kirlkhan in the northern end of the plain. The higher amount of localized rainfall is due to the fact that while Antakya lies east

${ }^{66}$ Jesse Casana, "Mediterranean Valleys Revisited: Linking Soil Erosion, Land Use, and Climate Variability in the Northern Levant," Geomorphology 101 (2008): 431; idem, "From Alalakh to Antioch," 46. 
of the Amanus Mountains, the mountains are lower in elevation and gradually roll down toward Antakya as foothills at this stretch of the range. The city's location in a valley at the foot of the steeper Syrian Jebels to the east puts Antakya on the windward side rather than the leeward side of the mountains and in a rain shadow. ${ }^{67}$ As such, while the area is conducive to severe storms and flash flooding, one has to keep in mind the variability of precipitation between Antakya and the rest of the Amuq Plain. Various studies attempting to reconstruct ancient climates have stated that between the fifth and ninth centuries C.E., the Levant was wetter and more humid, suggesting that there was greater storm activity. ${ }^{68}$

Three rivers flow into the plain: the Kara Su, Afrin, and Orontes. The Kara Su from the north and the Afrin from the east flow into the plain and terminate in the Lake of Antioch. The Afrin has meandered across the plain in several courses throughout history. The Orontes once flowed along the southern plain and connected with the outlet lake channel (Küçük Asi) south of the Lake of Antioch where it flowed out of the plain through the city of Antioch/Antakya and to the Mediterranean. Another river, known as the Yaghrā, although visible only by its channel bed in satellite imagery, flowed from the northeast and merged with the Kara Su at some point north of the lake. By the 1950s, most of the Amuq Plain was taken up by the large central lake and outlying marshes covering the land to the north, east, and south.

Small lakes and marshes have been documented since the Chalcolithic and permanently since the Hellenistic period. ${ }^{69}$ Cores drilled in the center of the

${ }^{67}$ Jacques Weulersse, L'Oronte: Étude de fleuve (Tours, 1940), 26-27. I would like to thank an anonymous reviewer for bringing the variability of rainfall in the Amuq to my attention.

${ }^{68}$ Oreste Reale and Paul Dirmeyer, "Modeling the Effects of Vegetation on Mediterranean Climate during the Roman Classical Period, Part I: Climate History and Model Sensitivity," Global and Planetary Change 25 (2000): 163-84; Oreste Reale and Jagadish Shukla, "Modeling the Effects of Vegetation on Mediterranean Climate during the Roman Classical Period, Part II: Model Simulation," Global and Planetary Change 25 (2000): 185-214.

${ }^{69}$ Casana, "From Alalakh to Antioch," 69; Tony J. Wilkinson, "The History of the Lake of Antioch: A Preliminary Note," in Crossing Boundaries and Linking Horizons: Studies in Honor of Michael C. Astour, ed. Gordon Young, Mark Chavalas, and Richard E. Averbeck (Bethesda, 1997), 557-76; Tony J. Wilkinson et al., "Geoarchaeology of a Lake Basin: Spatial and Chronological Patterning of Sedimentation in the Amuq Plain, Turkey," in Recherches
Lake of Antioch demonstrated that a body of water with beaches existed around 5560 B.C.E. and progressively became a marsh environment or larger lake by the mid-Holocene. Starting around 4000 B.C.E., the lake/marsh began to dry, and it remained dry from 3000 B.C.E. until the first millennium B.C.E. ${ }^{70}$ This is evidenced by the formation of weak paleosols followed by stable paleosols above the earlier lake clays. Two sites found by the Amuq Valley Regional Projects survey (AS 180, AS 181) within the Lake of Antioch exhibited banded clays overlaid with sand, indicating they may have been dry land or beach settlements. ${ }^{71}$ Their occupation dated to the Early Bronze Age and Early Iron Age interim period when the plain was relatively dry.

From the first millennium B.C.E., upper levels of lacustrine clays and shelly mud at AS 180 showed that a lake and expanding marsh reformed and continued until the present day. Silt/clay deposits from the lake covered the sites that were pre-Roman. ${ }^{72}$ There are two major factors for this phenomenon: (1) sedimentation from upland erosion (alluvial fans and colluvial gravel), and (2) sedimentation from river and canal flooding (avulsion and aggradation). Increased levels of certain locally occurring metals such as chromium indicate that these were deposited on the plain from the eroded soils of the Amanus Mountains. Furthermore, this sedimentation in the lake was not steady, but rather episodic. Some salient, albeit more tentative, interpretations of the data revealed that the accumulated water-logged soils were significantly weathered and pollen preservation in the cores was poor, indicating that water on the plain may never have been deep and expanded and contracted intermittently, exposing the water's sediments of soil and pollen. ${ }^{73}$

The evidence revealed by the cores for upland erosion and sedimentation can be elaborated in other geomorphological studies around the plain. To the northwest of the plain, large, alluvial gravel fans have

en archéométrie 1 (2001), 211-26; K. Aslıhan Yener et al., "Amuq Plain Regional Project, 1995-1998," American Journal of Archaeology 104.2 (2000): 163-219.

${ }^{70}$ Casana, "From Alalakh to Antioch," 62-63; Wilkinson et al., "Geoarchaeology of a Lake Basin," 220-22.

${ }^{71}$ Yener et al., "Amuq Plain Regional Project, 1995-1998," 175-76.

${ }^{72}$ Ibid.

${ }^{73}$ Wilkinson et al., "Geoarchaeology of a Lake Basin,” 222. 
been detected at the base of the Amanus Mountains. At the Arpalı pits, deposits of sediment up to $6 \mathrm{~m}$ deep of high-energy episodic flows covered Hellenistic architectural horizons. A section in the Bakras Valley showed similar gravels several meters thick covering a Late Roman land surface. These alluvial fans, like the permanent marsh, are late features in the landscape as evidenced by the sealing-in of a Hellenistic wall and the lack of early sites on the alluvial fans, which must be obscured by the colluvium and gravel flows. ${ }^{74}$ Furthermore, they show the significant contribution of erosion on the plain. A particularly salient detail is the intensity of erosion not only above Hellenistic levels but above Late Roman levels, which shows it was a by-product of the intensive upland cultivation explosion of the Roman and Late Roman periods.

Canal systems and irrigated fields in the plain would have been an important factor in the sedimentation of the plain and formation of wetlands. In the center of the plain, canal systems detected on the ground (from up-cast soil along the banks) and from CORONA satellite imagery clearly show irrigation channels linearly diverging off the main Kara Su and Afrin Rivers. During the Roman/Late Roman period, the Eski Afrin B course of the Afrin River was straightened and bifurcated in the section nearest to the lake. Varying deposits of sedimentation from cores suggested a shift from predominant deposition of Kara Su or Afrin River silt to mainly Orontes River sediment. The Orontes River, five times larger than either the Kara Su or Afrin Rivers, was prone to a high level of seasonal fluctuation in volume. ${ }^{75}$ Flooding on the plain from the Orontes River was periodic with alternating episodes of aggradation and stability caused by the avulsion process demonstrated both in Mesopotamia and the Ghab. In fact, the canalization of the Ghab in the Roman period may have increased the volume of water in the Amuq. ${ }^{76}$ Greater and larger sand deposits in the upper levels of sedimentary sec-

\footnotetext{
${ }^{74}$ Casana, "From Alalakh to Antioch," 75; see also idem, "Mediterranean Valleys Revisited," 429-42, for an extensive discussion with data on soil erosion in the plain.

${ }^{75}$ The Arabic name of the Orontes, al-'Asi ('the Rebel'), alludes to the unpredictable character of the river. (This process is illustrated today, although in part artificially amplified by two major floods in 2000 and 2003 that have severely inundated the plain around Atchana demonstrating a causative factor of marsh formation by heavy sedimentation.)

${ }^{76}$ Casana, "From Alalakh to Antioch," 363.
}

tions near Tell Atchana show that the Orontes shifted to a high-energy flowing river around the first century C.E. ${ }^{77}$ forming a post-Roman levee. ${ }^{78}$ The Orontes flood plain was rapidly aggraded, contributing to the same marshification process caused by the irrigation canals and upland cultivation that would have occurred sometime during the Early Islamic period. ${ }^{79}$ Recent evidence from thirty-five cores around the mound of Tell Tayinat corroborates the flooding of the Orontes River basin. These cores contained bands of coarse sand grains indicative of a small shallow lake around Tayinat in the early ninth century B.C.E. occurring during the initial occupation of the site in the Iron Age. ${ }^{80}$ The coring evidence from Tayinat showed sediment aggradation on the plain at a rate of $1 \mathrm{~mm}$ per year or $1 \mathrm{~m}$ per millennium. Thus, by the end of the Early Islamic period, the plain would have risen nearly $2 \mathrm{~m}$ from the Iron Age period. The Princeton University excavation in Antioch in the 1930s revealed up to $6 \mathrm{~m}$ of alluvial Orontes sediment covering Roman levels. While heavier sedimentation occurred in the southern part of the plain in the Orontes River basin, which partially explains the occasional formation, growth, and persistence of wetlands, the gradual infilling of sediment on the entire Amuq Plain would have occurred with varying intensities.

The Lake of Antioch formed between the seventh and fourth centuries B.C.E., to judge from documentary evidence that refers to the Hellenistic city of Antigonia, precursor to Antioch, founded on a lake during the late fourth century B.C.E. and from the absence of a lake in the Bronze and Iron Age sources. ${ }^{81}$ This corresponds with the transition from the Iron Age

${ }^{77}$ Wilkinson et al., "Geoarchaeology of a Lake Basin,” 214.

${ }^{78}$ Yener et al., "Amuq Plain Regional Project, 1995-1998," 169.

${ }^{79}$ Casana, "Mediterranean Valleys Revisited," 439.

${ }^{80}$ This was at $3 \mathrm{~m}$ below the surface all around the mound radiating out up to the site of Tayinat al-Saghir, corresponding with the textual mention of the Neo-Assyrian King Shalmaneser II (858 в.с.E.) who was only able to access the great swamp of Unqi (Amuq) by flat-bottomed boats. Ground Penetrating Radar (GPR) data showed an expansion of the lower city of Tayinat into the area of the former lake/marshland later during the Iron Age, indicating that the marshes were drained. See Stephen Batiuk and Timothy Harrison, "Towards Understanding the Iron Age Lower Mound at Tell Tayinat" (paper presented at the annual meeting of ASOR, Philadelphia, 2005).

${ }^{81}$ Casana, "From Alalakh to Antioch," 65. This is corroborated by the coring evidence from the lake around Tayinat (Batiuk and Harrison, “Towards Understanding," 5). 
to Seleucid/Hellenistic periods (and presumably new cultivation and irrigation systems on the plain) and closely parallels the same human activities in southern Iraq during the Neo-Babylonian/Hellenistic transition. The boundaries of the lake remained relatively stable and unchanged until recent times. Pottery from the beach ridges dated to the Roman and Late Roman periods can establish when the lake attained its size. However, following the formation of the marsh, which would postdate the Late Roman beach ridges to the end of the Late Roman (seventh century) or Early Islamic period, it can be extrapolated that the boundaries between lake and marsh (or even the distinguishing factors between lake and marsh) were, at best, undefined. The lake may have been the permanent section of a later-developed, seasonally dynamic marsh linked with Orontes River flooding (as evidenced by the shift to Orontes sediment and episodic deposition). The Lake Gölbaşı core, northeast of the Lake of Antioch, was similar and showed that Lake Gölbaşı formed slightly later, during the Hellenistic/Roman periods (see fig. 6).

Braidwood stated that the formation of marshes in the Amuq was caused by a gradual sedimentation of the lake's outlet. ${ }^{82}$ The evidence shows that formation of the marsh and lake was a complicated process not solely caused by either natural (storm activity) or manmade causes (such as erosion from vegetation loss due to intensive upland cultivation, mining, timber farming, settlement, and increased canalization and irrigation around the plain) but was augmented by both cultural activity and natural occurrences. Rather intensive mixed cultivation of olives, grapevines, grain, and orchards on the upland slopes in the Hellenistic, Roman, and Late Roman periods contributed to great landscape sensitivity and erosion susceptibility. During punctuated episodic periods of high rainfall (storms and flash floods), erosion would deposit 3.5-5.0 m of alluvial sedimentation on the plain and valley floors. ${ }^{83}$ The heavy sedimentation contributed significantly to the expansion and permanence of the wetlands by the Early Islamic period.

\footnotetext{
${ }^{82}$ Robert Braidwood, Mounds in the Plain of Antioch: An Archaeological Survey, Oriental Institute Publications 68 (Chicago, 1937), 10.

${ }^{83}$ Casana, "Mediterranean Valleys Revisited," 438; idem., "From Alalakh to Antioch," 51-52, 433-34; Wilkinson et al., "Geoarchaeology of a Lake Basin,” 224.
}

CORONA satellite imagery (dated December 1970) shows the continued spread of marsh in the Islamic periods. A curtain of pale sediment-lacustrine clays-encroaching on former agricultural fields and canal systems post-dates the marsh expansion on the northeast corner of the lake to after the Late Roman period. ${ }^{84}$ The "canalized" Roman/Late Roman branch of the Afrin was not immediately inundated, as it sat upon a raised levee. While the CORONA is very useful in locating the extent of the marsh, dating the expansion of the marsh is difficult using the imagery. Part of this problem is that the expanded marsh becomes an extension of the lake and the river channels become difficult to define. However, although marsh expansion covers parts of the Kara Su and Yaghrā Rivers in the CORONA image, the existence of the rivers is affirmed by textual evidence in the fourteenth and nineteenth centuries C.E. Presumably, they would have been central waterways through the marsh. ${ }^{85}$ Early twentieth century descriptions state that the wetlands covered an area of $310 \mathrm{~km}^{2}$ (nearly 50 percent of the plain), $220 \mathrm{~km}^{2}$ of which were marsh while $90 \mathrm{~km}^{2}$ were lake. Weulersse in the 1930s divided the plain generally by elevation with the lake between $78-80$ m.a.s.l, the marsh between $80-83$ m.a.s.l., and dry, cultivated land above 83 m.a.s.l. In the summer, two separate marshes were visible in addition to the lake and separated from it by a sand bar. The southeast marsh was called Karagöl, watered by the Afrin, 30$40 \mathrm{~km}^{2}$ in extent, and $80-100 \mathrm{~cm}$ deep. The northeast marsh was called Sarısu Gölü, watered by the Kara Su and Yaghrā Rivers, and $90 \mathrm{~km}^{2}$ in extent. Both were covered with reeds and sedges while the open Lake of Antioch was devoid of vegetation except on its perimeter. ${ }^{86}$ The lake was crossed in one day even when skirting its edges and avoiding the open water, which was a slower route. ${ }^{87}$

Literary evidence does not refer to a marsh in the plain until the Islamic period. Previous references to the Amuq Plain in the Late Roman period by Libanius and Malalas seem to refer only to a lake and

${ }^{84}$ AS 92 (Tell Karacanlik), north of the lake in the marsh, showed a sequence of Late Roman agricultural soils covered by marsh lacustrine clays.

${ }^{85}$ William F. Ainsworth, Travels and Researches in Asia Minor, Mesopotamia, Chaldea, and Armenia (London, 1842), 1:37.

${ }^{86}$ Korkmaz, "Antakya-Kahramanmaraş Grabenindeki," 36-39.

${ }^{87}$ Ainsworth, Travels and Researches, 1:37. 
canal systems, although this may be the result of a mistranslation of words that have changed meaning (such as the ambiguity of lake and swamp) that will be discussed below. Geomorphological, archaeologi$\mathrm{cal}$, and literary evidence supports the formation of a marsh by at least the end of the Late Roman period and start of the Early Islamic period.

\section{Settlement}

Now that marsh formation has been established as an Early Medieval anthropogenic process, a second problem, equally important to an analysis of marshes, is their associated settlement after formation. Academic scholarship on the subject of marsh settlement in antiquity is strangely sparse, and, unfortunately, ancient literary references to marshes are equally scant. ${ }^{88}$ This may be associated in part with modern perceptions that tend to dismiss marshlands as peripheral and uninhabited malarial zones within the landscape. ${ }^{89}$ In addition, marshes are considered as obstacles to travel and transportation, particularly for the large commer-

\footnotetext{
${ }^{88}$ Traina (Paludi e bonifiche) explains that part of the problem is that marshes were so common and infused within the normal pastoral/agricultural world by the fifth century B.C.E. that there was no need to mention them and when they were mentioned they were associated negatively (pp. 50,78) or with natural disasters (pp. 32, 49, 77).

${ }^{89} \mathrm{McNe}$ ill argues that malaria was not a significant deterrent to settlement until the seventeenth-twentieth centuries, as partly evidenced by flourishing coastal cities (J. McNeill, Mountains of the Mediterranean World: An Environmental History [New York, 1992], 345). The significance of acute malaria in shaping the relationship between coastal dwellers and the environment has been discussed elsewhere, as a threat inherent to the wetland areas of the Troad (northern Aegean in Turkey) during both prehistoric and historical periods (Rüstem Aslan, "The Relationship between Man and Landscape in the Troad during the Ottoman Period," in Troia and the Troad: Scientific Approaches, ed. Günther A. Wagner, Ernst Pernicka, Hans-Peter Uerpmann [Berlin, 2003], 31-41; Ursula Wittwer-Backofen, "Regional Palaeodemographic Aspects of Troia and Its Ecosystem," in Troia and the Troad: Scientific Approaches, 303-15). It is also known from the ethnographic record elsewhere that the presence of mosquitoes in wetland areas influenced human decisions (Betty Meehan, "A Matter of Choice? Some Thoughts on Shell Gathering Strategies in Northern Australia," in Animals in Archaeology 2: Shell Middens, Fishes, and Birds, ed. Caroline Grigson and Juliet Clutton-Brock, BAR International Series 227 (Oxford, 1983), 3-16.
}

cial and trade-based economies that dominated the Near East following the first millennium B.C.E.

It is problematic to assume a static settlement pattern that avoided the marshes and clung to the peripheral dry zones. Wetlands are key ecological resources both for settlement and subsistence, their annually renewed resources providing reeds and sedges for construction materials (along with animal fodder) and wildlife such as fish, waterfowl, and pigs for food..$^{90}$ Wetland inhabitation can take place beside the two traditional Near Eastern subsistence strategies of wheat/barley cultivation and sheep/goat pastoralism. ${ }^{91}$ Unfortunately, marsh settlements, characterized by their location within the marshes themselves and mainly constructed of reed and mud brick, are frequently imperceptible in the archaeological record, because (1) these areas are often in highly aggraded sedimentary zones and obscured from survey; and (2) settlements would have been constructed mainly of organic materials and would not be preserved today. As such, although they are "landscapes of destruction" or "zones of attrition," 92 the settlement of these landscapes must be reconstructed through ethnographic, literary, and available survey evidence.

\section{Ethnographic Evidence}

Ethnographic evidence demonstrates that marsh regions revealed adaptive patterns of settlement that, until the twentieth century, were relatively unaffected by industrial and modern impositions..$^{93}$ Further, inhabitants of these regions often trace themselves back through a long ancestry and have been described as having changed little over hundreds of years: “. . . car il n'y a pas dans toute la Syrie de population plus

${ }^{90}$ Pournelle, "Marshland of Cities," 251-52.

${ }^{91}$ Ibid., 19; Adams also includes garden/orchard cultivation as a fourth subsistence strategy (Robert McC. Adams, The Evolution of Urban Society: Early Mesopotamia and Prehispanic Mexico (Chicago, 1969), 48.

${ }^{92}$ Tony J. Wilkinson, Archaeological Landscapes in the Near East (Tucson, 2003), 43.

${ }^{93}$ Many of these marsh inhabitants have disappeared as a result of modernization, draining of wetlands, and sedentarization. Nevertheless, as pockets of groups still exist, they are here referred to in the present tense. 
arriérée ni plus primitive." ${ }^{94}$ As such, they provide a viable lens with which to reconstruct the marsh settlements of antiquity.

Marsh settlement occurs in two places: either on the many ancient tells that rise above the waters, or on small islands ( $\bar{\imath} \operatorname{s} h \bar{a} n)$ built of stacked rushes and mud or packed alluvium and enclosed by reed fences. ${ }^{95}$ The houses and virtually everything else are made of reeds bonded with clay and water buffalo dung. In Iraq, these often assume elaborate constructions of thick reed pillars and barrel-vaulted reed roofs. The door and window openings are of adjustable reed mats. During floods, the floor levels are easily raised or low barriers are built around the islands. In the Ghab, the houses, enclosing a single rectangular space for man and animal, have reed coverings and brick foundations over stone beds. Indeed, reeds are fundamental for all parts of life. In Iraq, each of the various types is used for a specific purpose such as tall reeds for canoe poles and shorter flexible reeds for building houses. ${ }^{96}$ They can also be used for making bags. ${ }^{97}$

Transportation between houses and through the marshes is and always has been by canoe (masshuf or tarrāda). These are constructed of mulberry wood and waterproofed with pitch or bitumen, an important resource in ancient Mesopotamia. In the Amuq, the Yörük used small, light barges with flat floors. ${ }^{98}$ Roads, when present, were raised causeways. ${ }^{99}$

Marsh dwellers subsist by raising water buffalo, fishing, hunting, and growing rice. Water buffalo are used mainly for their milk (and milk products such as butter, kaymak, labban, and cheese) and dung, which provides fuel and mortaring material. In the Amuq, water buffalo averaged 15-20 per household. ${ }^{100}$ Where marsh waters recede, small gardens of pepper, watermelon, and chickpeas are grown. In the Ghab, the dwellers use the enriched fertile, narrow strips of land between marsh and river or mountain to grow

${ }^{94}$ Weulersse, "Le Pays des Alouites," 375, referring to the marsh dwellers of the Ghab.

${ }^{95}$ Gavin Young, Return to the Marshes: Life with the Marsh Arabs of Iraq (London, 1977), 41.

${ }^{96}$ Fulanain, Haji Rikkan, 22-23.

${ }^{97}$ Korkmaz, "Antakya-Kahramanmaraş Grabenindeki," 41-42.

${ }^{98}$ Weulersse, L'Oronte, 59-60.

${ }^{99}$ Ainsworth, Travels and Researches, 1:38; W. J. Childs, Across Asia Minor on Foot (New York, 1917), 438.

${ }^{100}$ Korkmaz, "Antakya-Kahramanmaraş Grabenindeki," 41-42. barley, wheat, tobacco, sorghum, and sometimes rice and cotton. ${ }^{101}$ Fish provide a primary winter resource, specifically catfish and eel, but also barbell, carp, and round-tailed chub, which can also be sold and traded in markets. ${ }^{102}$ The marshes are thriving ecosystems containing a diverse array of wildlife including waterfowl (pelicans, herons, ibis, egrets, snipe, plover, storks, ducks, kingfishers, eagles, hoopoes, and the occasional flamingo), otters, and the infamous large and aggressive wild boars. ${ }^{103}$

In all three regions discussed here, marsh inhabitants who practiced a combination of pastoralist, sedentary, and marsh subsistence based on the seasonal expansion and recession of the marsh waters have been documented including the Ma'dān (Marsh Arabs) of southern Iraq ${ }^{104}$ the Nuṣayrī ('Alawī or Alaouites) of the Ghab Valley, and the Yörük Turkmen of the Amuq Plain. In southern Iraq, the lowland plains are cultivated in the summer by the semisedentary farmers of the marshes and grazed in the fall by semi-nomadic pastoralists from the northern uplands (see fig. 4). Marsh activities such as fishing, hunting, and reed cutting are practiced all year round; the reeds are used as fodder for the grazing sheep of the pastoralists, cattle/water buffalo of the farmers, and mats for settlements. ${ }^{105}$ Unique to the region and unlike the more northern areas such as the Ghab Valley and the Amuq Plain, little activity is undertaken in the high winter and early spring months from January to April. As the wetlands are constantly revitalized by annual flooding, activities like pasturing, agriculture, and reed gathering become perennial, patterned, seasonal activities

${ }^{101}$ Weulersse, "Le Pays des Alouites," 372.

${ }^{102}$ Ibid., 375; Vital Cuinet, La Turquie d'Asie: Géographie administrative, statistique, descriptive et raisonée de chaque province de l'Asie-Mineure, vol. 2 (Paris, 1890-95), 148. Ainsworth noted that the black catfish was a Roman luxury fish of the Orontes but not eaten by the locals (Travels and Researches, 1:38-39). In the Amuq in the early twentieth century, 100-150 tons of catfish, 80 tons of eel, and 200 tons of carp were noted to have been fished over one year, mainly for local consumption but also for export; see Korkmaz, "Antakya-Kahramanmaraş Grabenindeki," 41-42.

${ }^{103}$ Young, Return to the Marshes, 163.

${ }^{104}$ Barring the period between 1991 and 2003 when the marshes were drained and its inhabitants displaced under Saddam Hussein.

${ }^{105}$ Pournelle summarizes these activities into a "farmer's almanac" of subsistence strategies around Lake Suwaiqiya showing the combination of agriculture, pastoralism, and wetland subsistence ("Marshland of Cities," 231-39). 


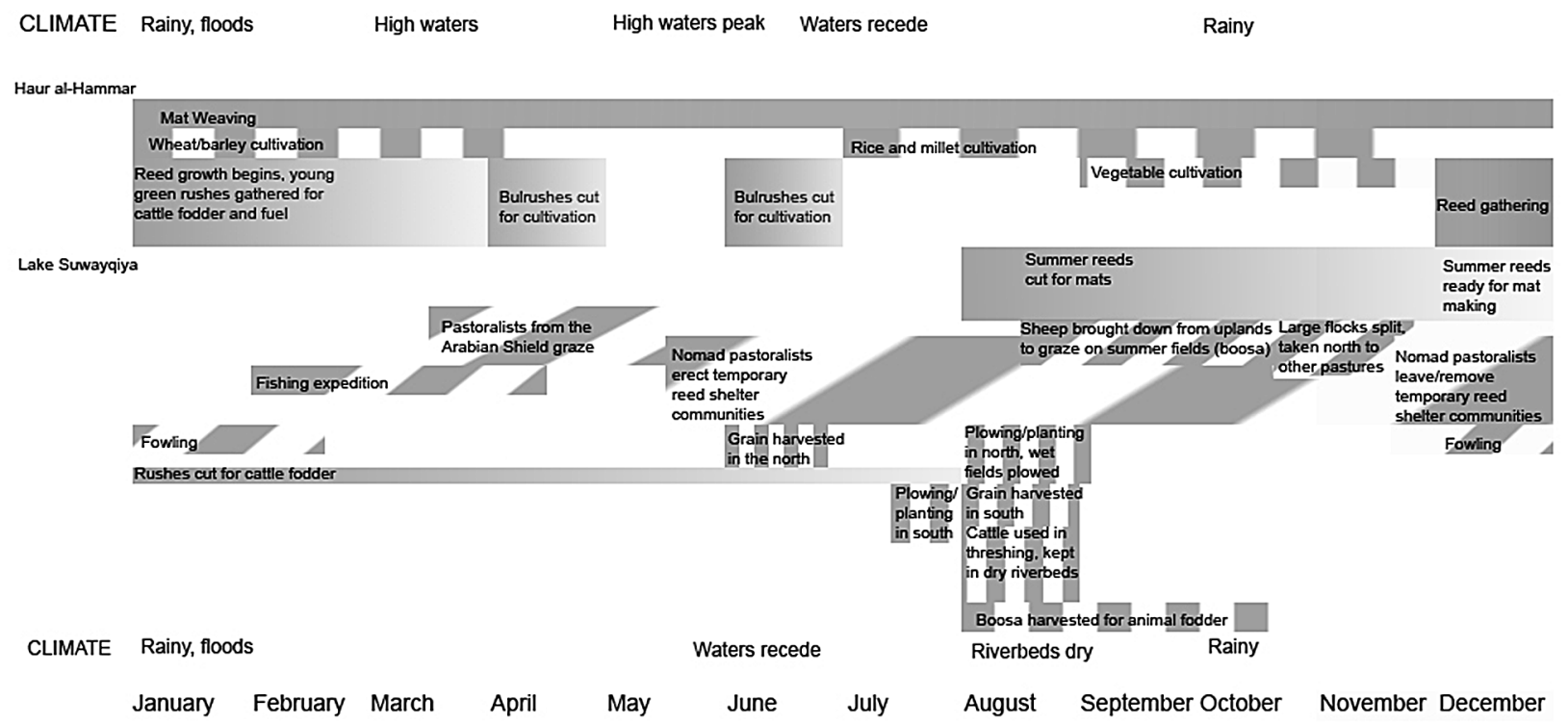

Figure 4-Southern Iraq "Farmer's Almanac" (derived from Jennifer Pournelle, "Marshland of Cities," pp. 231-39).

practiced by communities in mutually beneficial rather than competitive ways. ${ }^{106}$ The Ghab inhabitants also practice a seasonally dual way of life, though pasturing does not play a role in their lifestyle, indicating that subsistence of these inhabitants has shifted and/or pasture land is scarce. They settle on the peripheral alluvial fans at the foothills of the limestone mountains to the west when the plain is less inundated in the summer months, and they shift toward the center of the plain when the plain is inundated in the winter, abandoning the villages. The reason for the seemingly backward movement is certainly to place settlements in the most profitable area of a dual economic system: dry areas in the summer for grain, flooded areas in the winter for fish. The Yörük are traditionally nomadic mountain pastoralists who come down from their high summer pastures (yayla) in the Taurus in the north to winter pastures ( $k$ ¿şlak) in the plain, a cycle very similar to the Ghab settlement pattern. Unlike the Ghab, however, the people avoid living within the marshes, and live rather in goat hair tents on the many tells that rise from them. Settlement in the marshes caused them to adopt several wetland subsistence strategies, beyond simply using the wetlands as pastureland.

\footnotetext{
${ }^{106}$ Ibid., 256.
}

\section{Southern Iraq}

It may be assumed that settlement in ancient times followed similar trajectories and thus was not confined only to the dry peripheries. The reliance on ephemeral resources raises the issue of their visibility within an archaeological landscape. ${ }^{107}$ In southern Iraq, early evidence for wetlands settlement and land use comes from a small site (H3) dated to the Ubaid (5500-5300 B.C.E.) near the sea on the Kuwaiti coast northwest of Falaika Island. ${ }^{108}$ In addition to marine fish and fowl, wetland catfish and freshwater shells typical of those from the southern Mesopotamian marshes have been found. There is also faunal evidence for raising livestock and pastoralism in sheep/goat and cattle bones. Most interesting are the remains of a boat made of reeds and coated with bitumen, closely resembling the Ma'dān's watercraft. In the Jemdet Nasr period (3200-2900 B.C.E.) settlements were composed of detached chains of raised land separated by canals, resembling very closely the archipelago appearance of Ma'dān settlements. In the Early Dynastic period

${ }^{107}$ For example, see Carrie Hritz, “Appendix III: Remote Sensing of Sites in and around the Hawr al-Hammar and Hawr alHawiza," in The Persian Gulf Shorelines and the Karkheh, Karun, and Jarrabi Rivers: A Geo-Archeological Approach. A Joint BelgoIranian Project. First Progress Report-Part 3, ed. Herman Gasche, Akkadica 128 (2007): 63.

${ }^{108}$ Pournelle, "Marshland of Cities," 116. 
(2900-2350 в.C.E.) settlements were few and clustered together in semiurban centers. Although not explicitly evident, it can perhaps be assumed that the settlement groupings were within and separated by unoccupied areas of marshland. Adams, using the $\mathrm{Ma}^{\mathrm{c}} \mathrm{dā}$ as a modern parallel, perceived these as "marsh communities" and posed a seasonal occupancy by one social group that alternated between both sides of the river channels. ${ }^{109}$ For example, on the western bank there was plenty of water but settlements assumed nucleated (albeit subdivided by waterways) groupings dependent on the raising of buffalo and the use of their dung for island and house materials. Water buffalo are documented in Mesopotamia since the second half of the third millennium B.C.E. ${ }^{110}$ The larger settlements often showed a range of specialization (boat repairers, weavers, etc.). In the time of Sennacherib (704-681 B.C.E.) there was a settlement of Chaldean exiles called Nagitu, which was an island settlement and target for Sennacherib's naval campaigns. ${ }^{111}$ The presence of an "outlaw" group from the perspective of the ruling authority residing in marshes is an important sociopolitical pattern traced in later periods (see below).

Adaptation to the increasing marsh was demonstrated by a large Sasanian site (site 265) that also consisted of a cluster of small islands separated by water channels. ${ }^{112}$ Settlements on the eastern bank were smaller and relied on shallow wells. These were often found on mounds and consisted of a central settlement with peripheral houses for newer families or seasonally occupied by other families.

Settlement in the marshes was significant but qualitatively undetermined in the Islamic periods. According to Adams, only one site (site 006) of late 'Abbāsid date was found to the north of the Uruk/ Warka region and no later settlements were found until the fifteenth century. ${ }^{113}$ Adams and Nissen state that during the Islamic period the region experienced a decline in rural areas and renewed focus on urban centers. ${ }^{114}$ One main problem arises from this analysis: while the authors use modern ethnographic evidence

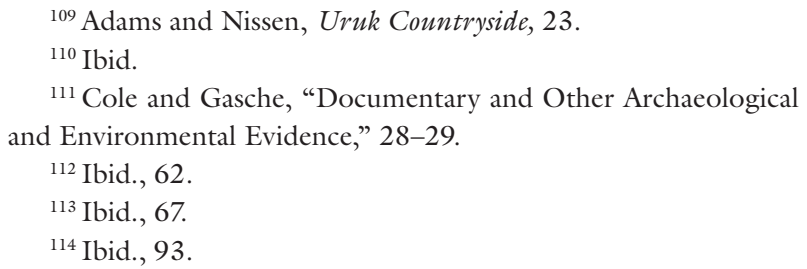

of the rural $\mathrm{Ma}^{\mathrm{c}} \mathrm{dan}$ as a parallel, their argument that the region experienced decline during the Islamic periods in favor of urban settlement is based on a decline in material culture-a body of material produced by semipastoralists that would not easily appear in the archaeological record. Pournelle records 422 sites in the Early Islamic period compared with 58 sites in the Middle Islamic from the Warka, Eridu, Nippur, and E. Gharraf survey areas combined. ${ }^{115}$ It is true that the important urban cities of Bașra and Kūfa, straddling the marshes and the newer intermediary city of Wāsiț, would have been centers for population and commerce. Indeed, when al-Hajjaj constructed Wāsit in 700 C.E., he built many dams and uprooted reeds in an attempt to reclaim the wetland. ${ }^{116}$ However, urban entities should not preclude the possibility of a continued settlement. Textual references to known structures in the marshlands appear throughout the Islamic periods and imply settlement. ${ }^{117}$ As Adams suggested, the marsh sites may be imperceptible. Their absence within the geographical sources as proper named communities may be more a function of their size and loose tribal organization. Furthermore, the presence of outlaw communities in the marshes would probably go unnoticed in any official or semiofficial geographical or historical text. ${ }^{118}$

${ }^{115}$ Pournelle, "Marshland of Cities," 83, 203, fig. 83. Settlement aggregates are from the Warka, Eridu, Nippur, and East Gharraf survey areas. For the Warka and Nippur surveys, see Adams and Nissen, Uruk Countryside; R. McC. Adams, Heartland of Cities: Surveys of Ancient Settlement and Land Use on the Central Floodplain of the Euphrates (Chicago, 1981); for the Ur-Eridu survey, see Henry Wright, "The Southern Margins of Sumer: Archaeological Survey of the Area of Eridu and Ur," in Heartland of Cities, ed. Robert McC. Adams, 295-338; and for the East Gharraf region, see the Iraq Directorate of Antiquities, Atlas al Mawaqi'al-athariyah fii al-'Iraq (Atlas of the Archaeological Sites of Iraq) (Baghdad, 1976).

${ }^{116}$ Al-Balādhurī, Futūh al-buldān, 408.

${ }^{117} \mathrm{Al}$-Balādhurī referred to a lighthouse in the swamp (Futuh albuldann, 411). Other sources in the early tenth century documented the export of salted fish from the marshes and described barges that transported cargoes to intermarsh canoes for transport. In addition, they mention towers and stations built on reed platforms (like the dibun ) to guard these trade routes from outlaws living in the swamps. For discussion on marshes in Islamic sources, see Guy Le Strange, The Lands of the Eastern Caliphate: Mesopotamia, Persia, and Central Asia from the Moslem Conquest to the Time of Timur (New York, 1976), 42.

${ }^{118}$ Marshes and swamps are frequently associated as the hideouts of bandits and rebels (see also preceding note). The 'Abbāsids were involved several times in quelling insurgents or trying to oust local 


\section{Ghab Valley}

Unfortunately, the state of archaeology for the Ghab is underdeveloped. A survey by Courtois listed seventeen sites in the marshes (nine to the north, eight to the south), but these were only named and not described or dated in any way. ${ }^{119}$ Following the explosion of olive and other cultivation in the uplands between the Seleucid/Hellenistic and Late Roman/Early Islamic periods, there was a regrowth of forest in the uplands. This would suggest an abandonment of upland fields and orchards (and attendant settlements) in favor of lowland plain settlement and cultivation, corroborating the Islamic patterns of settlement. While the Ghab marsh appears to show more prominence in the Islamic periods, perhaps due to its expansion, it certainly did not direct settlement to the upland slopes. Recent excavations in the Ghab at Tell Qarquir just south of the mound revealed an Early Islamic/Middle Islamic lower town in an area of former marsh that could have been an example of island ( $\bar{s} s \bar{a} \bar{n})$ settlement. Most of the faunal evidence showed wetlands subsistence and was dated by the pottery to the fourteenth century. ${ }^{120}$ It is interesting to note that the tell, rising about $30 \mathrm{~m}$ above the plain, was only slightly occupied and was perhaps given over to agriculture and pasture.

This evidence is corroborated by the aforementioned fourteenth-century geographer Abū al-Fidā', who described the marsh inhabitants and their settlements in the Ghab who were living in the middle of the Lake of Christians (bubairat al-nașārā) and were: “. . . Christian fishermen who live here in huts built on

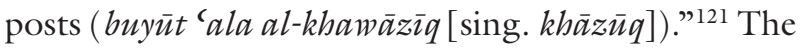
sites may be artificially built islands such as the $\bar{\imath} s \bar{a} n$ seen in southern Iraq made of reeds and mud, or they may be the tops of tells on the plain and along the silted and inundated main canal. The lake was populated by all manner of reeds and papyrus that would have been used in the day-to-day existence of these

outlaws from the marshes; see Alexandre Popović, The Revolt of African Slaves in Iraq in the 3rd/9th century (Princeton, 1999), 11 and "Imrān b. Shāhīn" in Encyclopedié de l'Islam, vol. 3, 12041205. In the fourteenth century, Ibn Bațūta described the region as full of Shiite bandits that raided caravans.

${ }^{119}$ Jacques-Claude Courtois, "Prospection archéologique dans la Moyenne Vallée de l'Oronte (el Ghab et er Roudj - Syrie du nordouest)," Syria 50 (1973): 53-99. Survey work has resumed in the Ghab under the Northern Ghab Regional Survey.

${ }^{120}$ Jesse Casana, personal communication, 2007.

${ }^{121}$ Abū al-Fidā', Kitā̄b taqwìm al-buld̄̄n, 41. inhabitants in constructing houses and the famous reed mats that were known to have been exported from marshes around the Levant such as the Hula in Palestine and the Biqā in Lebanon. Various waterfowl (including swans, pelicans, and cranes), fish, and eel would have been part of the diet of these Syrian marsh dwellers. When integrated within the larger economical framework of the Levant, the marsh dwellers may have maintained the Orontes waterways linking trade traffic between Himș, Hamā, and Anțākiya. What is interesting from Abu al-Fidā's comments on the marsh dwellers is that they are ethnically Christian communities, rather than Muslim. This suggests that either the adaptive strategies of marsh settlement and subsistence were learned from the Muslims who settled in the Early Islamic period, or they developed independently and simultaneously as a response to the environment.

Strabo calls the lake a leimnon-from limne, which is identified, specifically in Asia Minor (and the Levant), as a marsh and wet pasture distinguishable from helos, an undefined and more ecologically significant marsh. ${ }^{122}$ Strabo even specifically comments on the utilization of part of the plain as horse and cattle pasturage alongside of the activities of the marsh dwellers. This is important for large groups with horses such as nomads or armies. Increased pasturage and receding waters in the summer months or expanding marsh and isolated/peripheral dry areas of pasture merged two ecosystems that accommodated cultivated and pastoral settlement. As ethnographic evidence of the Nusāyrīs in the same region shows, inundated land and pastureland would not have prevented cultivation on the plain.

\section{Amuq Plain}

In the Amuq, archaeological evidence of marsh subsistence can be traced back to the Chalcolithic period when there were small lakes and marshes. Although it is unknown whether Chalcolithic Tell Kurdu was a marsh tell settlement or was located in close proximity to the wetlands, evidence from excavations uncovered reed matting used in domestic construction, large catfish bones, and a stamp seal of a large, storktype waterfowl catching a fish, indicating the importance of wetland subsistence both on a day-to-day

${ }^{122}$ Traina, Paludi e bonifichi, 54. 


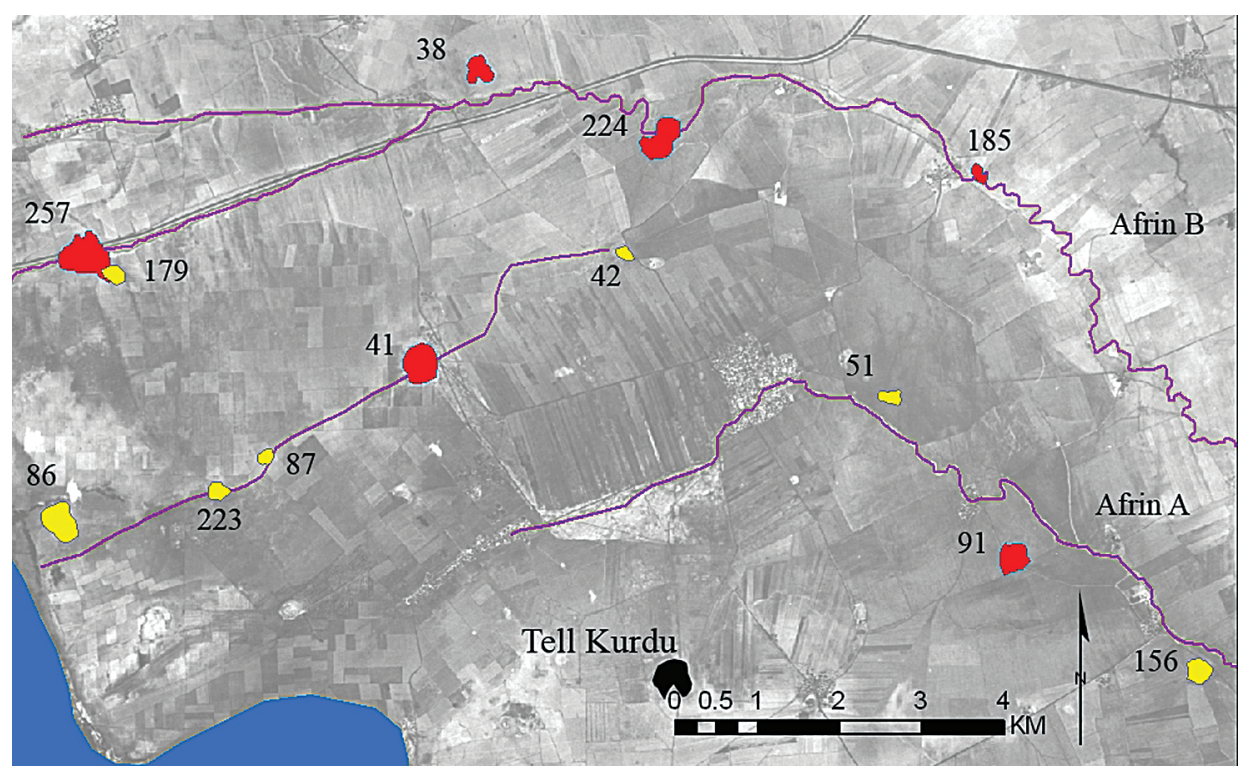

Figure 5-Amuq Plain with Canals and Sites Surveyed by the Amuq Valley Regional Project.

land-use scale and on a larger sociocultural/aesthetic scale. ${ }^{123}$ The early-middle second millennium and Late Roman site of Karatepe (AS 86) was constructed of mud bricks containing marshy soils. ${ }^{124}$ In the NeoAssyrian period, reliefs from the Balawat bronze gates in Mesopotamia in the kingdom of Muqish (Amuq) illustrated settlements surrounded by a limited extent of water (like a moat), suggesting that the inhabitants may have lived on islands. ${ }^{125}$

The archaeological evidence of dated sites within the marsh is more valuable. On the whole, the effects of marshification are evident in changing settlement patterns on the Amuq Plain. ${ }^{126}$ As the wetlands grew from the Lake of Antioch, occupation gradually shifted from seventh-century occupation in the west near the lake to early 'Abbāsid and Middle Islamic settlement to the east. However, the expansion of wetlands (in some cases to lakes) did not cause all settlements to

${ }^{123}$ Yener et al., "The Amuq Valley Regional Project, 19951998"; Rana Özbal and Fokke Gerritsen, "Tell Kurdu Excavations 2001," Anatolica 30 (2004): 37-75.

${ }^{124}$ Wilkinson, "History of the Lake of Antioch," 563.

${ }^{125}$ Ibid., 565 . This is corroborated by the coring evidence for the lake around Tayinat (Batiuk and Harrison, "Towards Understanding," 5).

${ }^{126}$ Fokke Gerritsen, Andrea U. de Giorgi, Asa Eger, Rana Özbal, and Tasha Vorderstrasse, "Settlement and Landscape Transformations in the Amuq Valley, Hatay: A Long-Term Perspective," Anatolica 34 (2008): 241-314. be abandoned. Rather, these shifts were gradual and several important sites remained within the marsh. Of the sites located in the marsh there are two main groups, located to the east and north of the Lake of Antioch. Many of these sites were tells discovered by Braidwood that were still surrounded by marsh and accessible only by boat. The group on the eastern side, south of the Afrin Canal B, has four sites (AS 86, 87, 223 , and 42 ) well within the marsh and linearly spaced, showing that they comprised part of a canal system for Afrin Canal A (see fig. 5). ${ }^{127}$ The canal would have been in use in the Late Roman period at least until the early seventh century and through the Early Islamic period as evident from a very large, seventh-century Early Islamic site, AS 41. The site does not continue past the tenth century when the channel likely became completely silted and the sites were abandoned due to marshification. A fifth marsh site south of this system was on a small tell near the lake. Although it had a larger preexisting Late Roman occupation, it remained occupied with the spread of marsh in the

\footnotetext{
${ }^{127}$ Gerritsen et al., "Settlement and Landscape," 268. Of these sites, AS 87 and AS 223 had some of the largest ceramic assemblages in the plain dating as late as the early seventh century C.E. but did not continue into the Early Islamic period. AS 41 was the second largest Early Islamic site on the plain with no Late Roman, Middle Islamic, or Late Islamic wares, occupied from the time of the Islamic conquests and located in the exact center of the plain.
} 


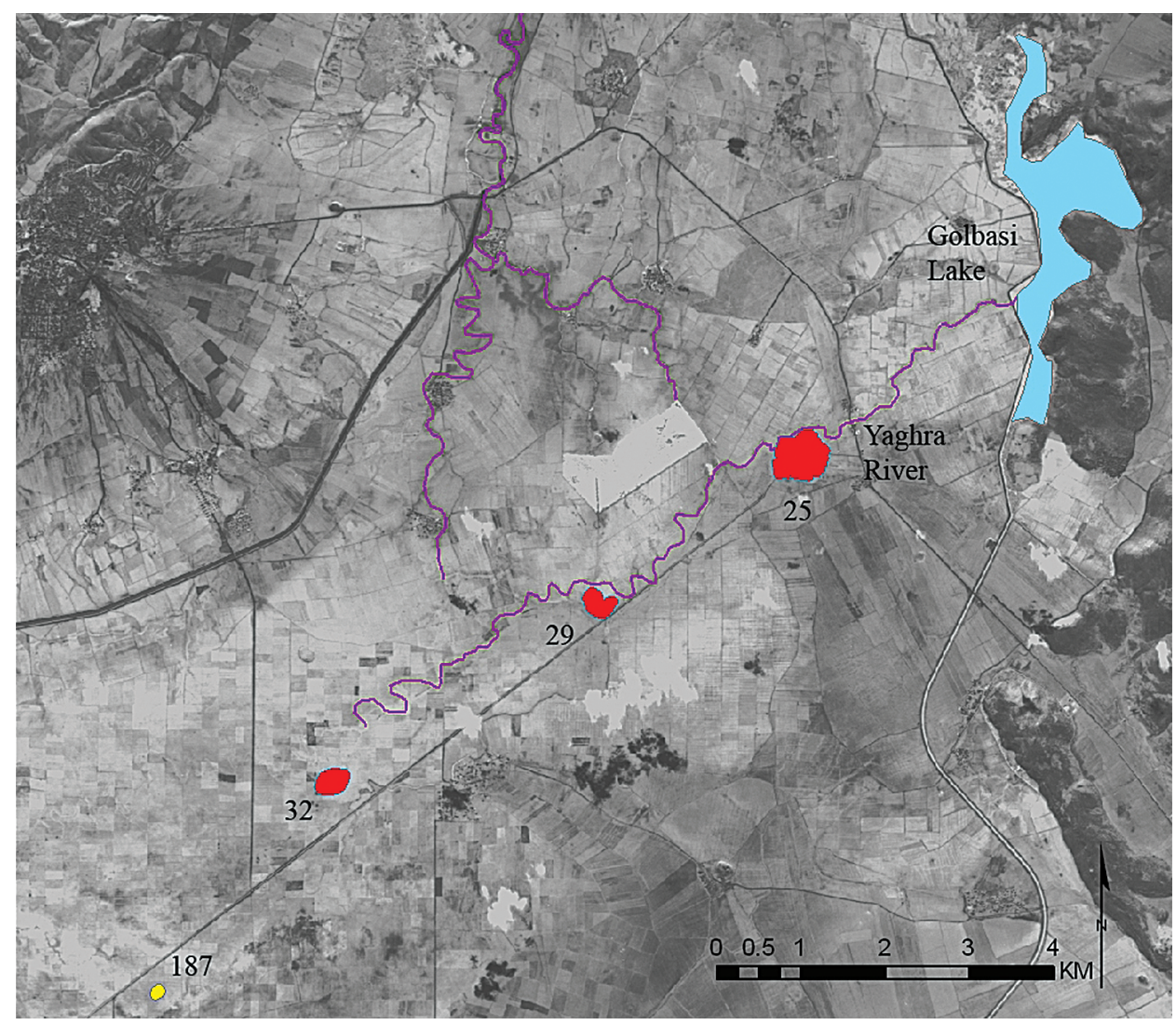

Figure 6-Amuq Plain with Yaghra River Site.

Early Islamic period. ${ }^{128}$ Early Islamic canals continued to be built in the plain with evenly interspersed canal/ marsh settlements divided into double mounds on either bank or along one bank as seen on the Afrin Canal B (AS 257, 224, and 185). The locations of these sites do not necessarily allow one to track the chronology of the encroaching marsh. Rather, the lack of continuity of sites shows a break between the Late Roman and Early Islamic that is uncharacteristic of many other sites in the Amuq Plain. ${ }^{129}$ The break is suggestive of a conscious settlement pattern away from (in the Late Roman period) or deliberately within (in the Islamic periods) the marsh ecosystem.

A second conspicuous grouping of the sites is evenly spaced along the Yaghrā River, which gradually

\footnotetext{
${ }^{128}$ However, the Early Islamic settlement at AS 89 shifted off the tell, as eighth-tenth century pottery did not come from the mound itself, but from a smaller adjacent mound.

${ }^{129}$ Such as the Yaghrā River sites of AS 29 and AS 32, sites in and around 'Imma/'Imm (AS 202, 345, 347), and the Tanışma Valley of the Jebel al-Aqra (AS 344).
}

became subsumed by wetlands, and was near a land route (see fig. 6). ${ }^{130}$ These three Yaghrā River sites (AS 32, 29, 25) show an interesting chronological development in their location. Although all three sites were contemporaneous and overlapped at some point during the Early Islamic period, decreasing percentages of Late Roman pottery from south to north and increasing percentages of Early Islamic (eighth-tenth centuries) and Middle Islamic pottery show a stronger occupational emphasis. ${ }^{131}$ Like the Afrin Canal sites,

${ }^{130}$ Gerritsen et al., "Settlement and Landscape," 268-69. Of this group, two were founded in the Hellenistic and Roman periods, while the third dates to the seventh century C.E. The sites are arranged from northeast to southwest along the southern bank of the Yaghrā River. The sites also occupy midpoints on the east-west land route that crossed the northern part of the Amuq at the edge of the marsh, near the present-day road. The first and southernmost site along the Yaghrā was located at the point where the Yaghrā and Kara Su Rivers joined and disappeared into the extensive marsh wetlands extending north of the lake of Antioch.

${ }^{131}$ This is emphasized by AS 187, located nearer to the lake and farther downstream on the Yaghrā River. The site, south of AS 32, 
this is a good cultural indicator of the process of marshification that continued to expand north of the lake. Indeed, from the Middle Islamic period until today, the Yaghrā River gradually became entirely subsumed within the wetlands. Although the process of marshification was more extensive for the Yaghrā River sites than for the Afrin Canal sites (which were raised), the Yaghrā River sites were larger Early Islamic sites in terms of assemblages. The sites remained occupied in the Middle Islamic period, showing that inhabitants built the sites higher and subsisted within a permanent wetlands environment. Despite the spread of marsh, the sites along the river waterways not only continued to function but grew in size and in importance as islands along the river route through the marsh. Like the Ma'dān settlements of southern Iraq, these major sites would have maintained the river as a main transportation and economic waterway through the marsh that perhaps also supplied smaller archaeologically imperceptible island marsh villages.

That the lake and marshes were rich in resources is known from texts by the fourteenth century when Abū al-Fidā' wrote that the lake "is covered with reeds, and there are fish and birds here the like to which we have mentioned in describing the Lake of Afāmiya." 132 Referring to Gölbaşı Lake (Buhaira Yaghrā) to the northeast, he stated: "It is called also Buhairah asSallūr [catfish] —which last is the Eel, called also alJirrī [eel] — by reason of the number of these fishes found in its water." 133

However, marsh settlement can be inferred as early as the seventh century. Mu'âwìya relocated and settled tribes of Zutt and Sayābija Indians from the marshes of southern Iraq (al-Bațāih $).{ }^{134}$ The Zutț (or Sindī) and Sayābija were originally from the Indus Valley and Sumatra and were brought to settle the area of Bașra in the Sasanian and Early Islamic periods

had no Late Roman or Early Islamic occupation. It was a large Roman site with good assemblages of both Hellenistic and Roman pottery. The absence of ceramics postdating the second century C.E. suggests that it was entirely submerged and left in favor of sites farther upstream. The site was reinhabited in the Middle Islamic period as a marsh site.

${ }^{132} \mathrm{Abū}$ al-Fidā', Kitāb taqwìm al-buldān, 42. Translation following Le Strange, Palestine under the Moslems, 71-72.

${ }^{133}$ Le Strange, Palestine under the Moslems, 72.

${ }^{134}$ Al-Balādhurī, Futuḥ al-buldān, 230. In the Umayyad period, the caliph al-Walīd imported four thousand water buffalo from alHind (India) to take care of a lion menace. for use as mercenaries and swamp laborers. ${ }^{135}$ They were transported to Syria, the Amuq, and Antioch, and subsequently to other frontier thughür towns of Mașsịșa, 'Ayn Zarba, and Kanīsat al-Sawdā throughout the Early Islamic period. A marsh ecosystem was certainly vital to their new residence in the Levant. They came with their families and thousands of water buffalo, ready to continue their wetland-based mode of life. Their involvement as either mercenaries on the frontier or new settlers is unclear and perhaps not altogether mutually exclusive. During the early conquests, when the marsh was known to have existed, the Amuq Plain was a central staging area, and then following the establishment of the thughür frontier to the north, the Amuq was a winter garrison for raids into Byzantine land. Apocalyptic prophecies produced in the frontier town of Hims near the Ghab Valley specifically allude to the meadows of the Amuq as a battleground for one of the final battles. ${ }^{136}$ Once the thugh $\bar{u} r$ line on the southern Taurus was established, the Amuq was incorporated into the 'awāsim province that supplied the frontier settlements to the north. The armies marched from the Amuq and 'awassim territory during the summer months when the Taurus Mountains could be traversed and the plain was driest. In the winter when the plain was inundated, they did not leave and raid, but rather chose to remain and made use of it as a wet pasturage, particularly as the waters receded by early spring. The extent to which the waters retreated is still a question, particularly as the marsh became more permanent.

\section{Conclusions}

The wetlands of the Near East were regions of settlement and subsistence throughout various periods of history since at least the Chalcolithic period. However, it is difficult to argue that wetland settlements were prolific. Archaeological investigation of these sites is complicated by their ephemeral construction and imperceptibility within the landscape. Wetland settlements have been documented as an adaptation to changing environmental conditions and the formation and growth of marshes, such as the major

\footnotetext{
${ }^{135}$ Paul Wheatley, The Places Where Men Pray Together: Cities in Islamic Lands, Seventh through the Tenth Centuries (Chicago, 2001), 44.

${ }^{136}$ Wilferd Madelung, "Apocalyptic Prophecies in Hims in the Umayyad Age," Journal of Semitic Studies 31.2 (1986): 158-74.
} 
expansion and permanence of wetlands in the Early Medieval period. Wetlands have also been settled in response to changing social or political conditions (by outlaw communities, for example). Not every community settled within wetlands; settlements were a function of certain groups following familiar patterns or developing necessary adaptive strategies.

It is possible to trace a cyclical system of agricultural intensification and semipermanent lakes beginning by the first millennium B.C.E., followed by permanent marshes by the sixth century C.E. formed in low-lying basins around the Near East. These depressions were always susceptible to waterlogging and marshes occurred in earlier periods. However, the collapse of the intensive upland cultivation and mining (deforestation) and lowland irrigation (canal building) works characteristic of and implemented during the Seleucid/Hellenistic and Late Roman/Early Islamic periods, and the removal or abandonment of regulatory control and maintenance procedures, primarily contributed to creating a precarious and unbalanced ecological system. Natural processes (such as more humid climatic conditions, greater precipitation, more frequent storms, and occasional seismic activity) induced the system to fail over time in periodic episodes. The combination of mainly human factors coupled with natural conditions in turn led to river flooding and avulsion, slope erosion, plain aggradation, and canal sedimentation. As such, in parts of the Near East, basins gradually filled, transforming seasonal lakes and marshland to permanent marsh. The early formation and expansion of the marsh, especially during seasonal inundations, would also have encouraged upland settlement, as noted by Tate and others in the Late Roman period for the region of the Dead Cities. ${ }^{137}$ This, in turn, would have caused increased sedimentation in the form of erosion and avulsion on the plain. While these cycles based on human land use were in effect before the first millennium B.C.E., the combination of the spread of upland settlements and the intensification of agricultural, irrigation, and other land use activities were crucial elements in the process of Early Medieval marshification.

\footnotetext{
${ }^{137}$ Gerritsen et al., "Settlement and Landscape," 258-60; Georges Tate, Les Campagnes de la Syrie du nord du Iie au VIIe siècle: Un exemple d'expansion démographique et économique dans les campagnes à la fin de l'antiquité (Paris, 1992).
}

The expansion of lake into marsh in the Islamic periods, coinciding with the abandonment of the region between the tenth and twelfth centuries as attested archaeologically, supports this hypothesis. However, settlement on the plains continued on a complex and adaptive scale. The southern Iraq, Ghab, and Amuq ethnographic models and literary evidence for patterns of settlements suggest that the lowland marshes were occupied beginning with inhabitants who used subsistence strategies that combined sedentary and pastoralist elements with marsh habitation. Settlement had to adapt to the physically changing landscape - the increasingly permanent and seasonally affected flooding of the rivers-and the politically changing landscape. In the Amuq and Ghab areas, the lowland marshy plains were also affected by the restructuring of the region in the seventh century C.E. as a political and military frontier zone where armies were assembled, mounts were pastured, and insurgent groups were resettled. Thus, like the formation of the marshlands, settlement was dictated by external factors that were both natural (seasonal growth and recession of marsh waters) and human (political and military).

In the Early Islamic period, the selection of frontier sites near marsh and pasture is an important connection that cannot be overlooked. Whitcomb suggested that early Muslims may have chosen to live in these areas, rather than reinhabit Byzantine cities, because they were more familiar with this type of landscape. ${ }^{138}$ This conscious repopulation of marsh/pasture areas implies a new or imposed pattern of settlement and land use. On the frontier, this settlement reveals three different (but not mutually exclusive) dynamics taking place. First, marsh settlement constituted a new form of adaptation to an increasing wetlands environment previously regarded as marginal. Marshlands were important ecological niches for certain types of inhabitants, supporting a way of life characterized by mixed cultivation, reed gathering, and fishing. ${ }^{139}$ The seasonal expansion and reduction of the marsh waters and the constantly renewed pastureland would have created a joint subsistence system. This system would have reduced stress on water supply, thereby also limiting competition for water resources. Such

\footnotetext{
${ }^{138}$ Donald Whitcomb, "Letters from the Field: In Search of Lost Mar'ash," The Oriental Institute News and Notes 171 (Fall 2001).

${ }^{139}$ Pournelle, "Marshland of Cities," 2003.
} 
dimorphic strategies are known from anthropological and ethnographic marginal environments. ${ }^{140}$ Second, marshes served military needs as they were prime areas for wet pasture. This is important for large groups with herding animals or horses such as pastoralists or armies, who were often one and the same and known from sources to have seasonally migrated upland in the summer and gathered and grazed in the winter in

${ }^{140}$ Michael B. Rowton, "Urban Autonomy in a Nomadic Environment," Journal of Near Eastern Studies 32 (1973): 201-15; Tony J. Wilkinson, "Water and Human Settlement in the Balikh Valley, Syria: Investigations from 1992-1995," Journal of Field Archaeology 25.1 (1998): 80. both the Ghab Valley of Hims and the Amuq Plain of Anțākiya. And last, the marsh was a politically marginal zone, a place for outlaws and bandits and also where insurgent groups could be settled either to remove them or destabilize an area from gaining power. In the Amuq Plain and other parts of the frontier, marsh dwellers from the wetlands of southern Iraq were settled there in the Early Islamic period. Responding to the changing environment and increased formation of marshes, they adapted to a familiar way of life as in their swamps of home, replicating similar settlements and subsistence strategies. 
Copyright of Journal of Near Eastern Studies is the property of University of Chicago Press and its content may not be copied or emailed to multiple sites or posted to a listserv without the copyright holder's express written permission. However, users may print, download, or email articles for individual use. 